\title{
LEVEL II SCOUR ANALYSIS FOR BRIDGE 12 (CHESVT01030012) on STATE ROUTE 103, crossing the WILLIAMS RIVER, CHESTER, VERMONT
}

U.S. Geological Survey Open-File Report 97-364

Prepared in cooperation with

VERMONT AGENCY OF TRANSPORTATION and

FEDERAL HIGHWAY ADMINISTRATION 


\section{LEVEL II SCOUR ANALYSIS FOR BRIDGE 12 (CHESVT01030012) on STATE ROUTE 103, crossing the WILLIAMS RIVER, CHESTER, VERMONT}

By ROBERT H. FLYNN and RONDA L. BURNS

U.S. Geological Survey Open-File Report 97-364

Prepared in cooperation with

VERMONT AGENCY OF TRANSPORTATION

and

FEDERAL HIGHWAY ADMINISTRATION 


\title{
U.S. DEPARTMENT OF THE INTERIOR BRUCE BABBITT, Secretary
}

\author{
U.S. GEOLOGICAL SURVEY \\ Gordon P. Eaton, Director
}

For additional information write to:

District Chief

U.S. Geological Survey 361 Commerce Way

Pembroke, NH 03275-3718
Copies of this report may be purchased from:

U.S. Geological Survey

Branch of Information Services

Open-File Reports Unit

Box 25286

Denver, CO 80225-0286 


\section{CONTENTS}

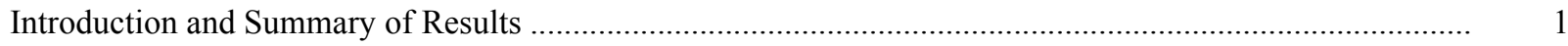

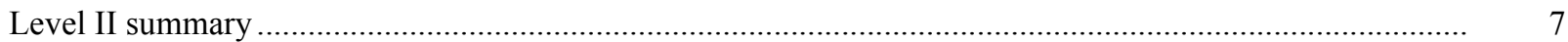

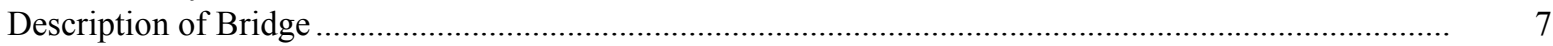

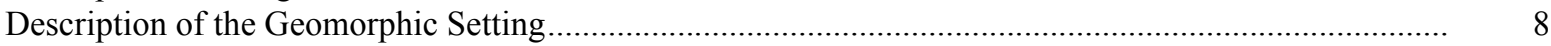

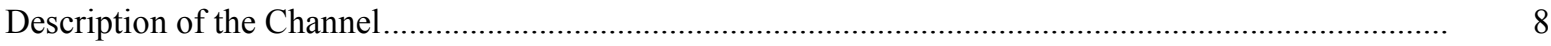

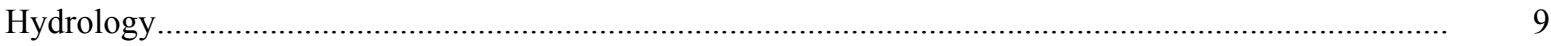

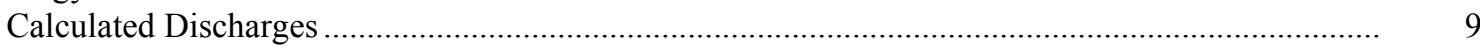

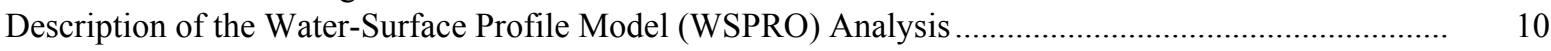

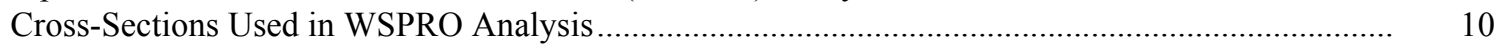

Data and Assumptions Used in WSPRO Model ...................................................................... 11

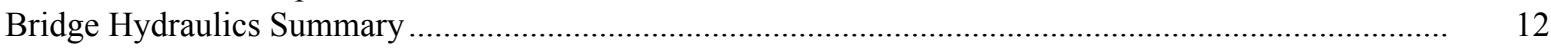

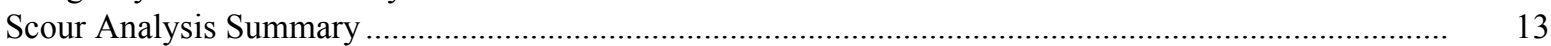

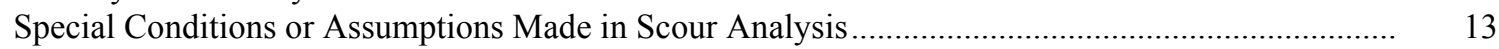

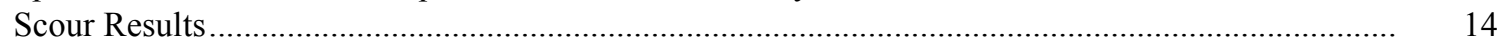

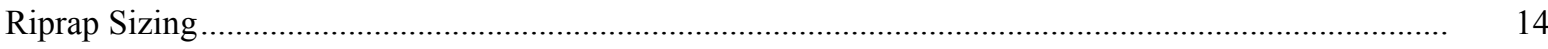

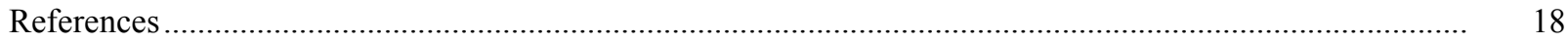

Appendixes:

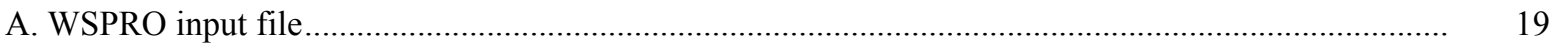

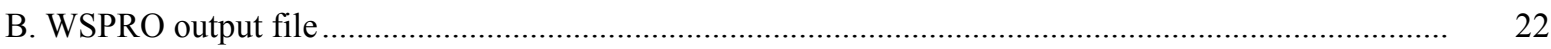

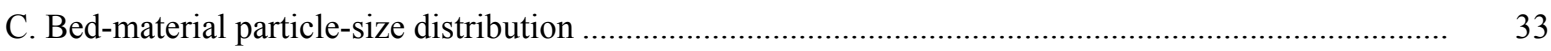

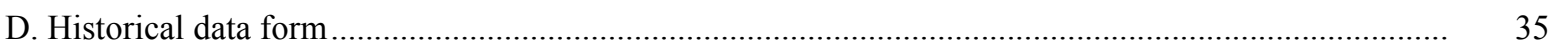

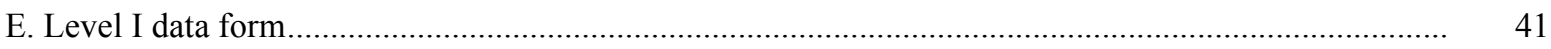

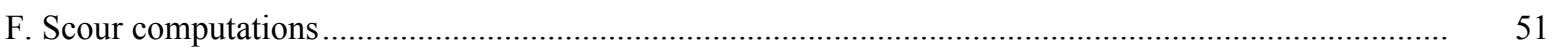

\section{FIGURES}

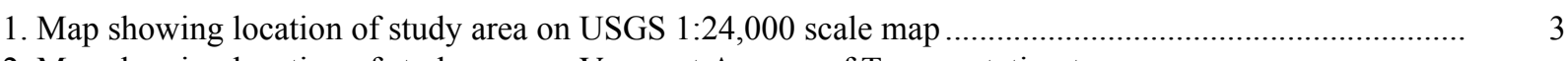

2. Map showing location of study area on Vermont Agency of Transportation town

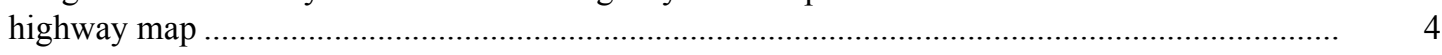

3. Structure CHESVT01030012 viewed from upstream (September 18, 1996) .........................................

4. Downstream channel viewed from structure CHESVT01030012 (September 18, 1996)........................ 5

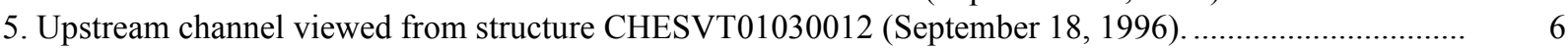

6. Structure CHESVT01030012 viewed from downstream (September 18, 1996)................................... 6

7. Water-surface profiles for the 100- and 500-year discharges at structure

CHESVT01030012 on State Route 103, crossing the Williams River,

Chester, Vermont.

8. Scour elevations for the 100- and 500-year discharges at structure

CHESVT01030012 on State Route 103, crossing the Williams River,

Chester, Vermont.

\section{TABLES}

1. Remaining footing/pile depth at abutments for the 100-year discharge at structure

CHESVT01030012 on State Route 103, crossing the Williams River,

Chester, Vermont

2. Remaining footing/pile depth at abutments for the 500-year discharge at structure

CHESVT01030012 on State Route 103, crossing the Williams River,

Chester, Vermont 


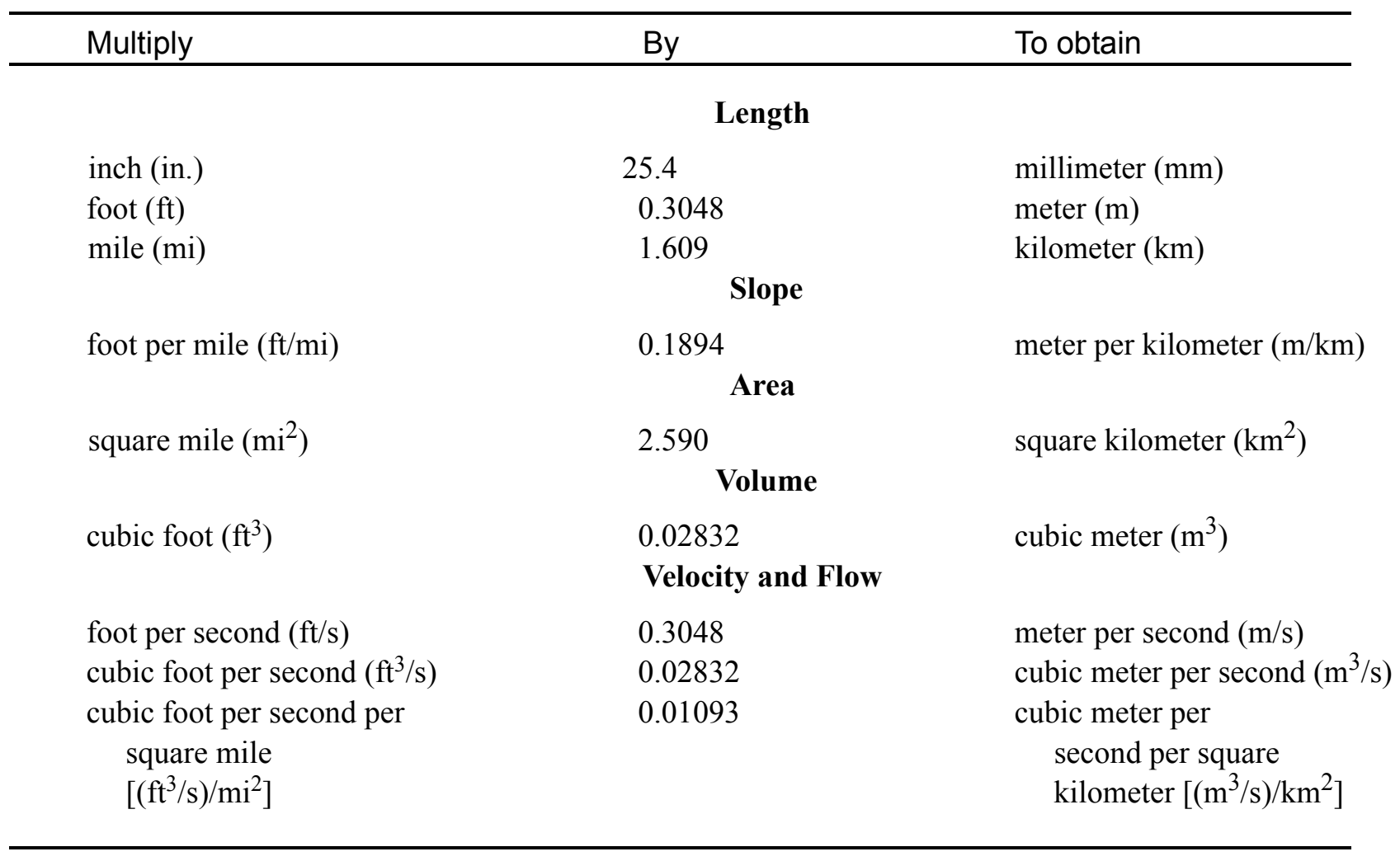

\section{OTHER ABBREVIATIONS}

$\begin{array}{lrlr}\mathrm{BF} & \text { bank full } & \text { LWW } & \text { left wingwall } \\ \mathrm{cfs} & \text { cubic feet per second } & \text { MC } & \text { main channel } \\ \mathrm{D}_{50} & \text { median diameter of bed material } & \text { RAB } & \text { right abutment } \\ \mathrm{DS} & \text { downstream } & \text { RABUT } & \text { face of right abutment } \\ \mathrm{elev} & \text { elevation } & \text { RB } & \text { right bank } \\ \mathrm{f} / \mathrm{p} & \text { flood plain } & \text { ROB } & \text { right overbank } \\ \mathrm{ft}^{2} & \text { square feet } & \text { RWW } & \text { right wingwall } \\ \mathrm{ft} / \mathrm{ft} & \text { feet per foot } & \text { TH } & \text { town highway } \\ \mathrm{JCT} & \text { junction } & \text { UB } & \text { under bridge } \\ \mathrm{LAB} & \text { left abutment } & \text { US } & \text { upstream } \\ \mathrm{LABUT} & \text { face of left abutment } & \text { USGS } & \text { United States Geological Survey } \\ \mathrm{LB} & \text { left bank } & \text { VTAOT Vermont Agency of Transportation } \\ \mathrm{LOB} & \text { left overbank } & \text { WSPRO } & \text { water-surface profile model }\end{array}$

In this report, the words "right" and "left" refer to directions that would be reported by an observer facing downstream. Sea level: In this report, "sea level" refers to the National Geodetic Vertical Datum of 1929-- a geodetic datum derived from a general adjustment of the first-order level nets of the United States and Canada, formerly called Sea Level Datum of 1929.

In the appendices, the above abbreviations may be combined. For example, USLB would represent upstream left bank. 


\title{
LEVEL II SCOUR ANALYSIS FOR BRIDGE 12 (CHESVT01030012) ON STATE ROUTE 103, CROSSING THE WILLIAMS RIVER, CHESTER, VERMONT
}

\author{
By Robert H. Flynn and Ronda L. Burns
}

\section{INTRODUCTION AND SUMMARY OF RESULTS}

This report provides the results of a detailed Level II analysis of scour potential at structure CHESVT01030012 on State Route 103 crossing the Williams River, Chester, Vermont (figures 1-8). A Level II study is a basic engineering analysis of the site, including a quantitative analysis of stream stability and scour (U.S. Department of Transportation, 1993). Results of a Level I scour investigation also are included in Appendix E of this report. A Level I investigation provides a qualitative geomorphic characterization of the study site. Information on the bridge, gleaned from Vermont Agency of Transportation (VTAOT) files, was compiled prior to conducting Level I and Level II analyses and is found in Appendix D.

The site is in the New England Upland section of the New England physiographic province in eastern Vermont. The $23.9-\mathrm{mi}^{2}$ drainage area is in a predominantly rural and forested basin. In the vicinity of the study site, the surface cover is pasture on the downstream right and upstream left overbank areas and short grass on the downstream left and upstream right overbank areas. The surface cover along the upstream and downstream immediate banks consists of trees and brush.

In the study area, the the Williams River has an incised, sinuous channel with a slope of approximately $0.0054 \mathrm{ft} / \mathrm{ft}$, an average channel top width of $75 \mathrm{ft}$ and an average bank height of $4 \mathrm{ft}$. The predominant channel bed material is gravel with a median grain size $\left(\mathrm{D}_{50}\right)$ of $52.4 \mathrm{~mm}(0.172 \mathrm{ft})$. The geomorphic assessment at the time of the Level I and Level II site visit on September 18, 1996, indicated that the reach was laterally unstable.

The State Route 103 crossing of the Williams River is a 99-ft-long, two-lane bridge consisting of three concrete T-beam spans (Vermont Agency of Transportation, written communication, March 29, 1995). The bridge is supported by two piers and vertical, concrete abutments with wingwalls and spill-through slopes. The channel is skewed approximately 20 degrees to the opening while the opening-skew-to-roadway is 0 degrees. Downstream of the bridge are the remains of a dam which is acting as a drop structure. 
A scour hole, approximately $3 \mathrm{ft}$ deeper than the mean thalweg depth, was observed along the upstream left bank extending from $78 \mathrm{ft}$ upstream of the upstream bridge face to $25 \mathrm{ft}$ downstream of the downstream bridge face during the Level I assessment. Lateral migration of the channel has resulted in flow being directed at an angle to the piers, which has resulted in increased local scour at the bridge. The scour protection measures at the site included type- 2 stone fill (less than 36 inches diameter) under the bridge along the entire base length of the left and right spill-through slopes and extending up to the abutments. Type- 2 stone fill (less than 36 inches diameter) scour protection was also found along the upstream left bank from the bridge to $46 \mathrm{ft}$ upstream and along the downstream right bank from the bridge to $70 \mathrm{ft}$ downstream. Rock walls were found along the left bank from $88 \mathrm{ft}$ to $200 \mathrm{ft}$ downstream and along the right bank from $124 \mathrm{ft}$ to $224 \mathrm{ft}$ downstream. There are two wood pile drop structures located at $47 \mathrm{ft}$ and $61 \mathrm{ft}$ downstream of the bridge. Additional details describing conditions at the site are included in the Level II Summary and Appendices D and E.

Scour depths and recommended rock rip-rap sizes were computed using the general guidelines described in Hydraulic Engineering Circular 18 (Richardson and others, 1995). Total scour at a highway crossing is comprised of three components: 1) long-term streambed degradation; 2) contraction scour (due to accelerated flow caused by a reduction in flow area at a bridge) and; 3 ) local scour (caused by accelerated flow around piers and abutments). Total scour is the sum of the three components. Equations are available to compute depths for contraction and local scour and a summary of the results of these computations follows.

Contraction scour for all modelled flows ranged from 0.0 to $0.2 \mathrm{ft}$. The worst-case contraction scour occurred at the 500-year discharge. Abutment scour ranged from 4.0 to $12.4 \mathrm{ft}$ along the right spill-through abutment and from 8.4 to $10.7 \mathrm{ft}$ along the left spillthrough abutment. The worst-case abutment scour occurred at the 500-year discharge. Pier scour ranged from 7.1 to $8.9 \mathrm{ft}$ along Pier 1 (northerly pier) and from 13.5 to $17.1 \mathrm{ft}$ along Pier 2 (southerly pier). The worst case pier scour occurred at the 500-year discharge. Additional information on scour depths and depths to armoring are included in the section titled "Scour Results". Scoured-streambed elevations, based on the calculated scour depths, are presented in tables 1 and 2. A cross-section of the scour computed at the bridge is presented in figure 8. Scour depths were calculated assuming an infinite depth of erosive material and a homogeneous particle-size distribution.

It is generally accepted that the Froehlich equation (abutment scour) gives "excessively conservative estimates of scour depths" (Richardson and others, 1995, p. 47). Usually, computed scour depths are evaluated in combination with other information including (but not limited to) historical performance during flood events, the geomorphic stability assessment, existing scour protection measures, and the results of the hydraulic analyses. Therefore, scour depths adopted by VTAOT may differ from the computed values documented herein. 


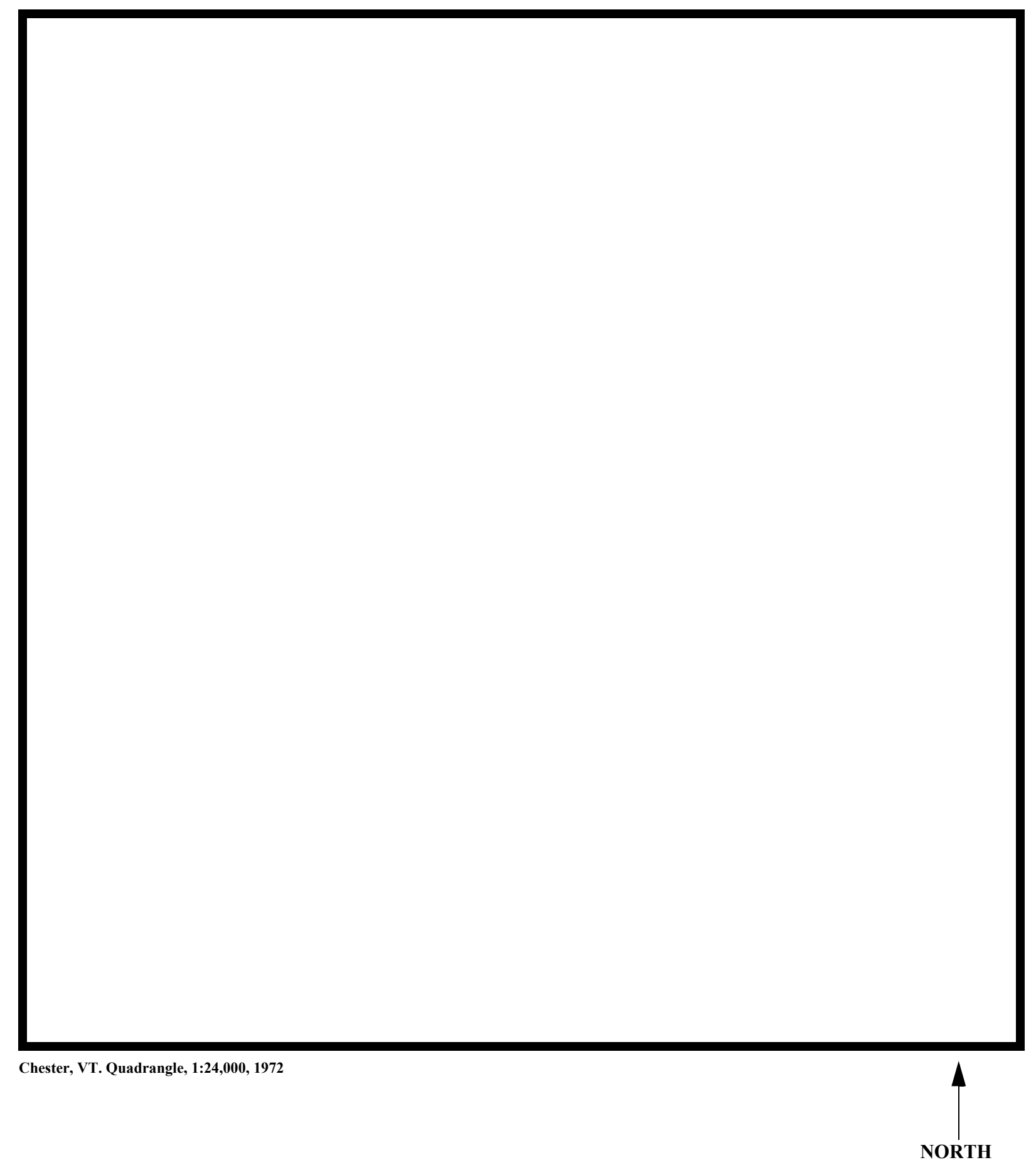

Figure 1. Location of study area on USGS 1:24,000 scale map. 
Figure 2. Location of study area on Vermont Agency of Transportation town highway map. 

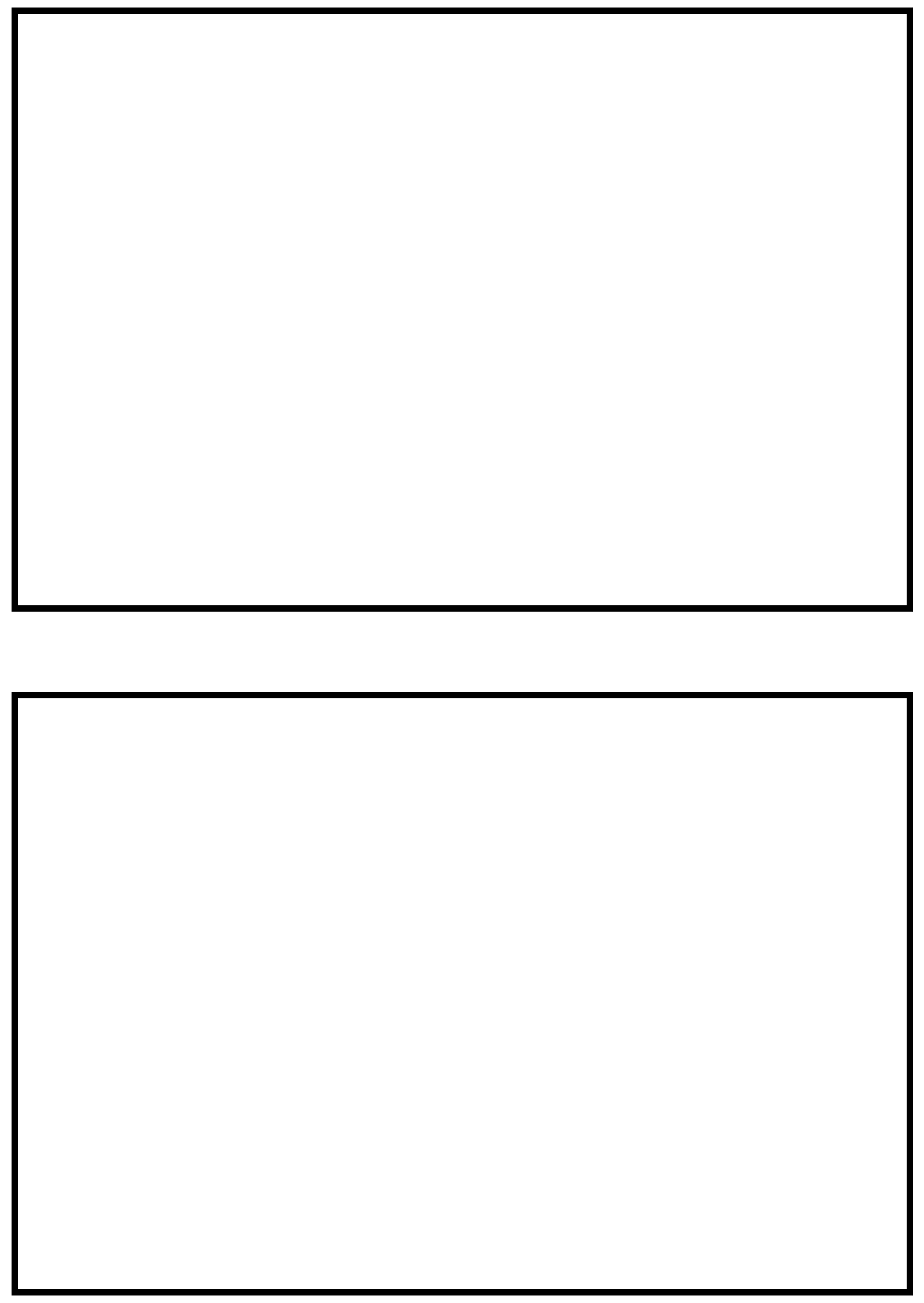

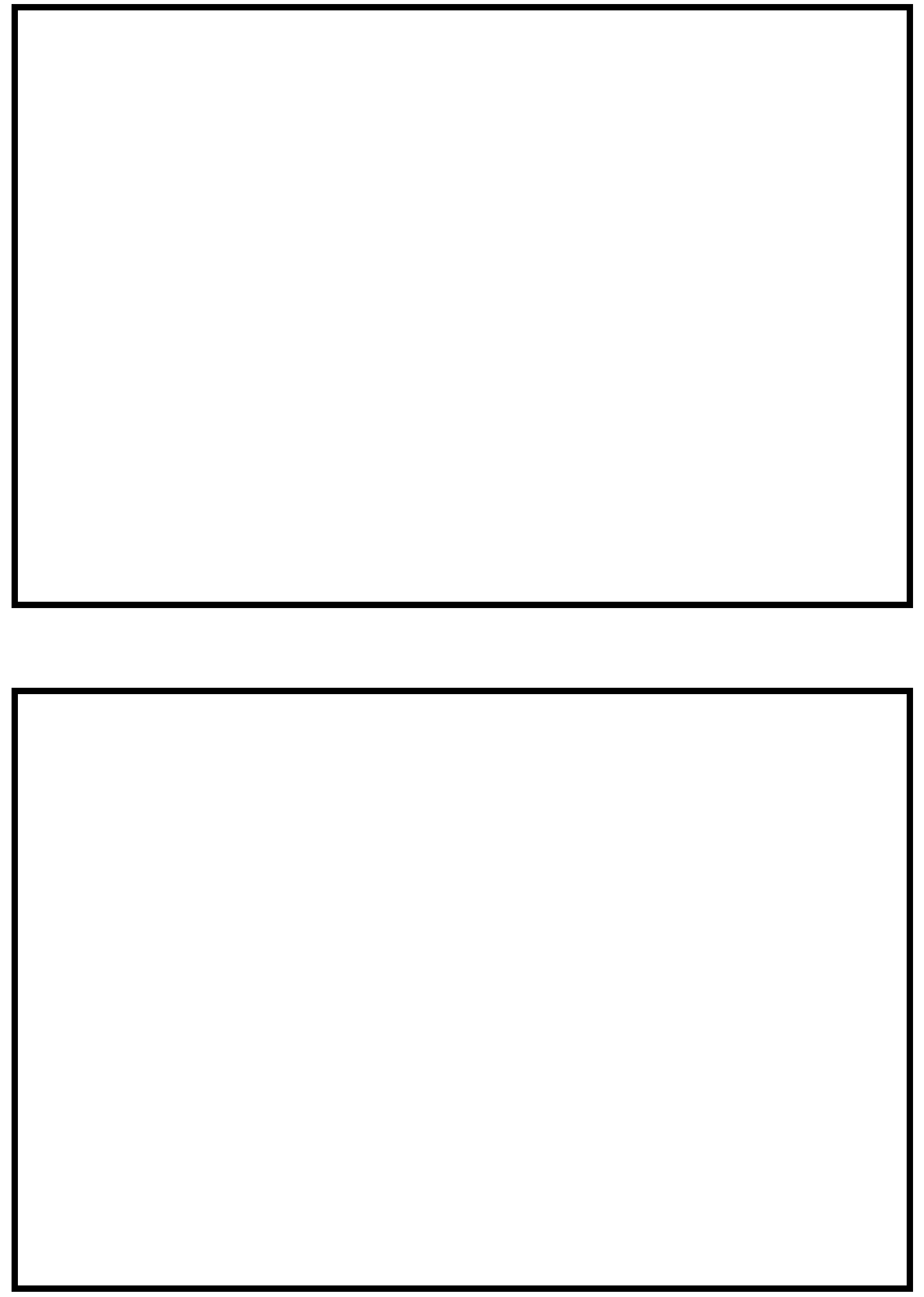


\section{LEVEL II SUMMARY}

\begin{tabular}{llllll} 
Structure Number & CHESVT01030012 & Stream & \multicolumn{2}{l}{ Williams River } \\
& Road & VT 103 & District & 2
\end{tabular}

\section{Description of Bridge}

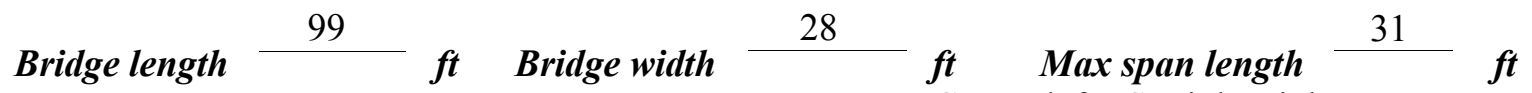

Alignment of bridge to road (on curve or straight)

Spill-through

Abutment type

Stone fill on abutment?

Yes

Embankment type

Curve, left; Straight, right

Sloping

9/18/96

nacmonintion af atans fill

Type-2, along the entire base length of the left and right spill-through abutments and extending up to the abutments.

Piers, abutments and wingwalls are concrete. Scouring

is evident at the piers.

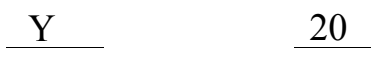

Is bridge skewed to flood flow according to No ' survey? Angle

There is a moderate channel bend in the upstream and downstream reach. The scour hole has

developed in the location where the bend impacts the upstream left bank and piers.

Debris accumulation on bridge at time of Level I or Level II site visit:

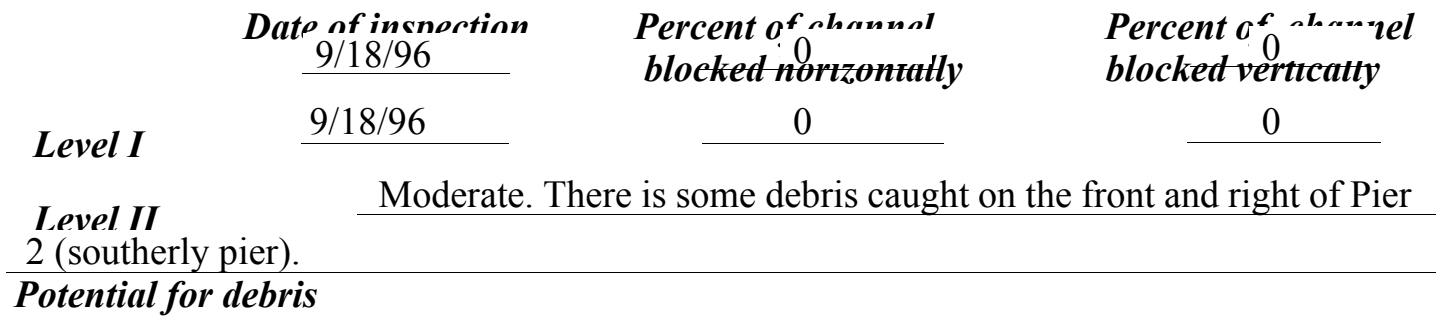

There is a point bar along the upstream right bank and two drop structures located approximately Doscriho any foaturos noar ar at tho hridoo that mav, affort flow, (includo ahsorvation dato) $47 \mathrm{ft}$ and $61 \mathrm{ft}$ downstream of the downstream bridge face as of 9/18/96. 


\section{Description of the Geomorphic Setting}

General topography The channel is located within a wide, flat to slightly irregular flood plain. 9/18/96

Geomorphic conditions at bridge site: downstream (DS), upstream (US)

Date of inspection Steep channel

DS left: $\quad$ bank to a narrow flood plain

DS right: $\quad$ Steep channel bank to a wide flood plain

US left: $\quad$ Steep channel bank to flood plain

US right: $\quad$ Steep channel bank to a wide flood plain

\section{Description of the Channel}

\begin{tabular}{|c|c|c|c|}
\hline \multirow[b]{2}{*}{ Average top width } & 75.0 & \multirow[b]{2}{*}{ Average depth } & \multirow{2}{*}{$\frac{4}{\text { Sand / Gravel }} \underset{f t}{ }$} \\
\hline & Gravel & & \\
\hline \multicolumn{2}{|c|}{ Predominant bed material } & Bank material & Sinuous and laterally \\
\hline \multicolumn{2}{|c|}{ unstable with semi-alluvial channel boundaries. } & $\ddot{*} \quad \cdot$ & \\
\hline
\end{tabular}

$9 / 18 / 96$

Vegetative co 1 TH 9 and grass on overbank with tree-s and b̈rush along banks

DS left: $\quad$ Grass on overbank with trees and brush along banks

DS right: $\quad$ VT 103 and grass on overbank with trees and brush along banks

US left: $\quad$ Grass on overbank with trees and brush along banks.

US right:

No

Do banks appear stable? Type-2 bank protection was found along the upstream left bank and is stabilizing the impact zone immediately upstream of the bridge but farther upstream, a point bar
date of observatton. along the upstream right bank and a cutbank along the upstream left bank indicate lateral migration of the upstream channel. In addition, the upstream and downstream bank material is primarily sand. Observed 9/18/96.

Flow conditions up to

bank-full level are influenced by a point bar on the right bank side of the upstream channel. In Describe any obstructions in channel and date of observation. addition, some debris is caught on Pier 2. 


\section{Hydrology}

Drainage area $\quad 23.9 \quad \boldsymbol{m i}^{2}$

Percentage of drainage area in physiographic provinces: (approximate)

Physiographic province/section New England / New England Upland
Percent of drainage area 100

Is drainage area considered rural or urban? Rural Describe any significant urbanization:

There are houses along the left overbank area

Yes

Is there a USGS gage on the stream of interest?

Williams River at Brockways Mills

USGS gage description

01153500

USGS gage number

103

Gage drainage area $\quad \mathrm{mi}^{2}$

No

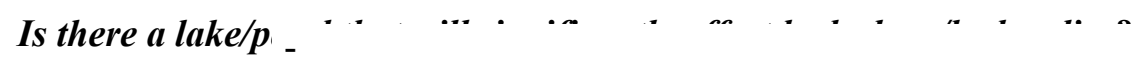

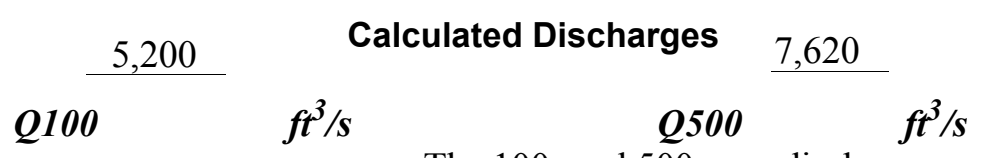

The 100- and 500-year discharges are based on a

drainage area relationship [(23.9/25.1)exp 0.75] with the Williams River above Trebo Brook in Chester which has flood frequency estimates available from the Flood Insurance Study for Chester (Federal Emergency Management Agency, 1982). 


\section{Description of the Water-Surface Profile Model (WSPRO) Analysis}

Datum for WSPRO analysis (USGS survey, sea level, VTAOT plans)

USGS survey

Datum tie between USGS survey and VTAOT plans

None

Description of reference marks used to determine USGS datum. $\quad$ RM1 is a chiseled X on

top of the downstream end of the right abutment (elev. $497.52 \mathrm{ft}$, arbitrary survey datum). RM2

is the bottom center of the letter "M" in the word "Vermont" on a brass tablet (VT bridge marker

\#T25B) on the upstream left end of the bridge rail (elev. $501.75 \mathrm{ft}$, arbitrary survey datum).

${ }^{1}$ For location of cross-sections see plan-view sketch included with Level I field form, Appendix E. For more detail on how cross-sections were developed see WSPRO input file. 


\section{Data and Assumptions Used in WSPRO Model}

Hydraulic analyses of the reach were done by use of the Federal Highway Administration's WSPRO step-backwater computer program (Shearman and others, 1986, and Shearman, 1990). The analyses reported herein reflect conditions existing at the site at the time of the study. Furthermore, in the development of the model it was necessary to assume no accumulation of debris or ice at the site. Results of the hydraulic model are presented in the Bridge Hydraulic Summary, Appendix B, and figure 7.

Channel roughness factors (Manning's " $n$ ") used in the hydraulic model were estimated using field inspections at each cross section following the general guidelines described by Arcement and Schneider (1989). Final adjustments to the values were made during the modelling of the reach. Channel " $\mathrm{n}$ " values for the reach ranged from 0.035 to 0.065 , and overbank " $\mathrm{n}$ " values ranged from 0.032 to 0.090 .

Normal depth at the exit section (EXTDS) of the downstream bridge (CHESTH00090063) was assumed as the starting water surface. This depth was computed by use of the slope-conveyance method outlined in the user's manual for WSPRO (Shearman, 1990). The slope used was $0.0054 \mathrm{ft} / \mathrm{ft}$ which was estimated from the topographic map (U.S. Geological Survey, 1972).

The surveyed approach section (APTEM) was moved along the approach channel slope $(0.002 \mathrm{ft} / \mathrm{ft})$ to establish the modelled approach section (APPRO), one bridge length upstream of the upstream face as recommended by Shearman and others (1986). This approach also provides a consistent method for determining scour variables. 


\section{Bridge Hydraulics Summary}

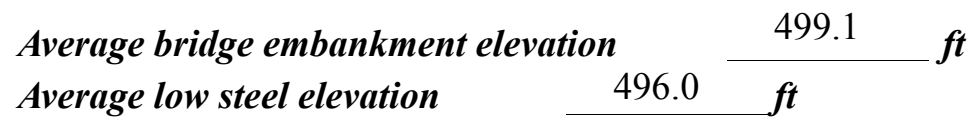

100-year discharge $\quad 5,200 \quad \mathrm{ft}^{3} / \mathrm{s}$

Water-surface elevation in bridge opening $491.2 \quad f t$

Road overtopping? ___ Y Discharge over road __ $313 \quad \mathrm{ft}^{3} / \mathrm{s}$

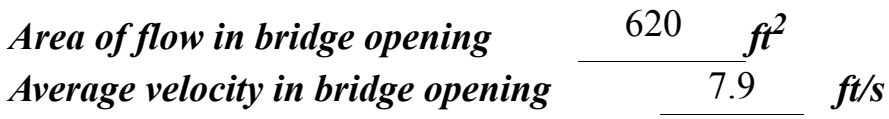

$\begin{array}{llll}\text { Maximum WSPRO tube velocity at bridge } & 9.9 & \mathrm{ft} / \mathrm{s}\end{array}$

Water-surface elevation at Approach section with bridge 493.1

Water-surface elevation at Approach section without bridge $\quad 491.9$

Amount of backwater caused by bridge $\quad 1.2$ it

500-year discharge $\quad 7,620 \quad \mathrm{ft}^{3} / \mathrm{s}$

Water-surface elevation in bridge opening $\quad 492.2 \mathrm{ft}$

Road overtopping? ___ Y Discharge over road __ 1,246 $\mathrm{ft}^{3} / \mathrm{s}$

\begin{tabular}{llll} 
Area of flow in bridge opening & $710 \quad \mathrm{ft}^{2}$ & \\
\cline { 2 - 3 } Average velocity in bridge opening & & $9.0 \quad \mathrm{ft} / \mathrm{s}$
\end{tabular}

Maximum WSPRO tube velocity at bridge 11.5 's

Water-surface elevation at Approach section with bridge 494.8

Water-surface elevation at Approach section without bridge $\quad 492.9$

Amount of backwater caused by bridge $1.9, t$

Incipient overtopping discharge $\quad 3,050 \mathrm{ft}^{3} / \mathrm{s}$

Water-surface elevation in bridge opening $490.3 \quad t$

Area of flow in bridge opening $\quad 552 \quad \mathrm{ft}^{2}$

Average velocity in bridge opening $\quad 5.5 \mathrm{ft} / \mathrm{s}$

Maximum WSPRO tube velocity at bridge $\quad 7.0 \mathrm{ft} / \mathrm{s}$

Water-surface elevation at Approach section with bridge

Water-surface elevation at Approach section without bridge

491.2

Amount of backwater caused by bridge $\quad 0.4$ it 


\section{Scour Analysis Summary}

\section{Special Conditions or Assumptions Made in Scour Analysis}

Scour depths were computed using the general guidelines described in Hydraulic Engineering Circular 18 (Richardson and others, 1995). Scour depths were calculated assuming an infinite depth of erosive material and a homogeneous particle-size distribution. The results of the scour analysis are presented in tables 1 and 2 and a graph of the scour depths is presented in figure 8 .

Contraction scour was computed by use of the clear-water contraction scour equation (Richardson and others, 1995, p. 32, equation 20). In this case, the 500-year discharge model resulted in the worst case contraction scour with a scour depth of $0.2 \mathrm{ft}$. The computed depths to streambed armoring suggest armoring will not limit the depth of contraction scour.

Abutment scour for the left abutment was computed by use of the Froehlich equation (Richardson and others, 1995, p. 48, equation 28). Variables for the Froehlich equation include the Froude number of the flow approaching the embankments, the length of the embankment blocking flow, and the depth of flow approaching the embankment less any roadway overtopping. Because scour processes on the spill-through embankment material is uncertain, the scour depth at the vertical concrete abutment walls is unknown. Therefore, the total scour depths were applied for the entire spill-through embankment below the elevation at the toe of each embankment and extended to the vertical concrete abutment wall as shown in figure 8 .

Scour at the right abutment was computed by use of the HIRE equation (Richardson and others, 1995, p. 49, equation 29) because the HIRE equation is recommended when the length to depth ratio of the embankment blocking flow exceeds 25 . The variables used by the HIRE abutment-scour equation are defined the same as those defined for the Froehlich abutment-scour equation.

Scour at the piers (piers 1 and 2) was computed by use of the Colorado State University (CSU) pier scour equation (Richardson and others, 1995, p. 36, equation 21). The variables used by the CSU equation include pier dimensions, flow approach depth and velocity, Froude number, and multiplicative factors for pier shape, attack angle, bed conditions, and armoring (see appendix F). 


\section{Scour Results}

100-yr discharge 500-yrdischarge

Incipient

Contraction scour:

(Scour depths in feet)

Main channel

Live-bed scour

Clear-water scour

Depth to armoring

Left overbank

Right overbank

Local scour:

Abutment scour

Left abutment

10.7

8.4

8.6

12.4

$4.0-$

8.3-

\section{Right abutment}

Pier scour

Pier 1

8.9

7.1

15.8

Pier 2

17.1

Pier 3

Abutments:

Left abutment

Right abutment

Piers:

Pier 1

Pier 2

\section{Riprap Sizing}

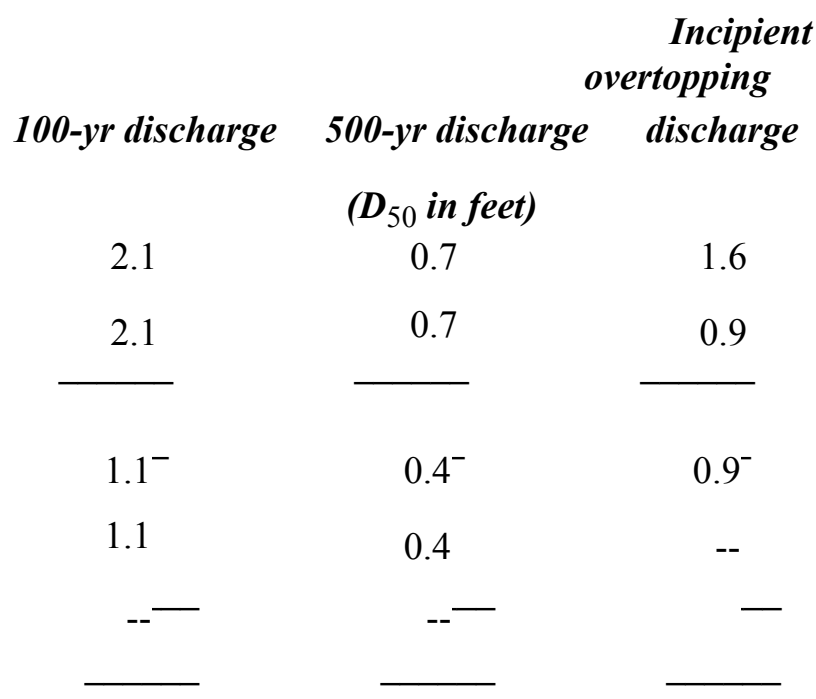




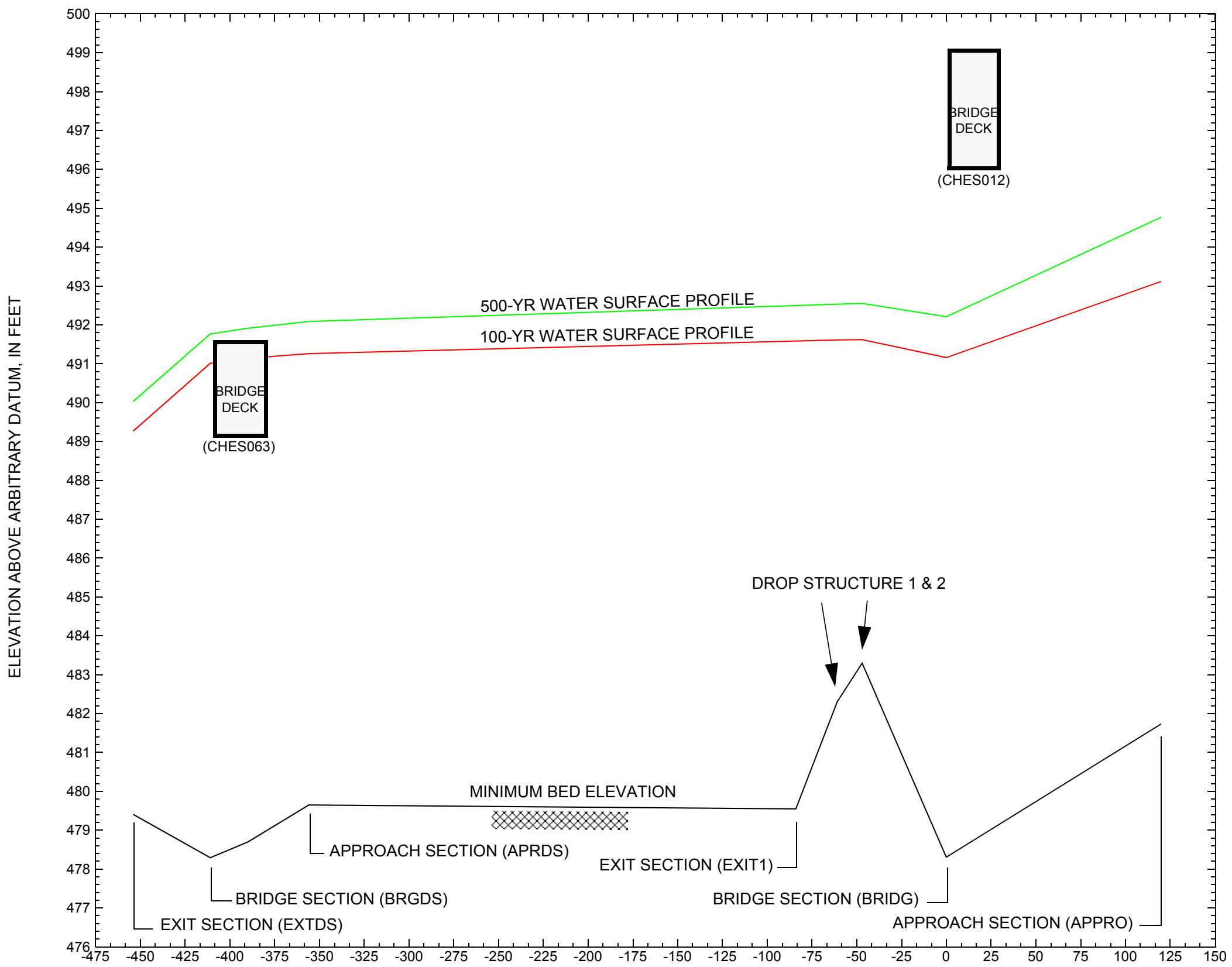

CHANNEL DISTANCE FROM DOWNSTREAM TO UPSTREAM, IN FEET

Figure 7. Water-surface profiles for the 100- and 500-yr discharges at structure CHESVT01030012 on State Route 103, crossing the Williams River, Chester, Vermont. 


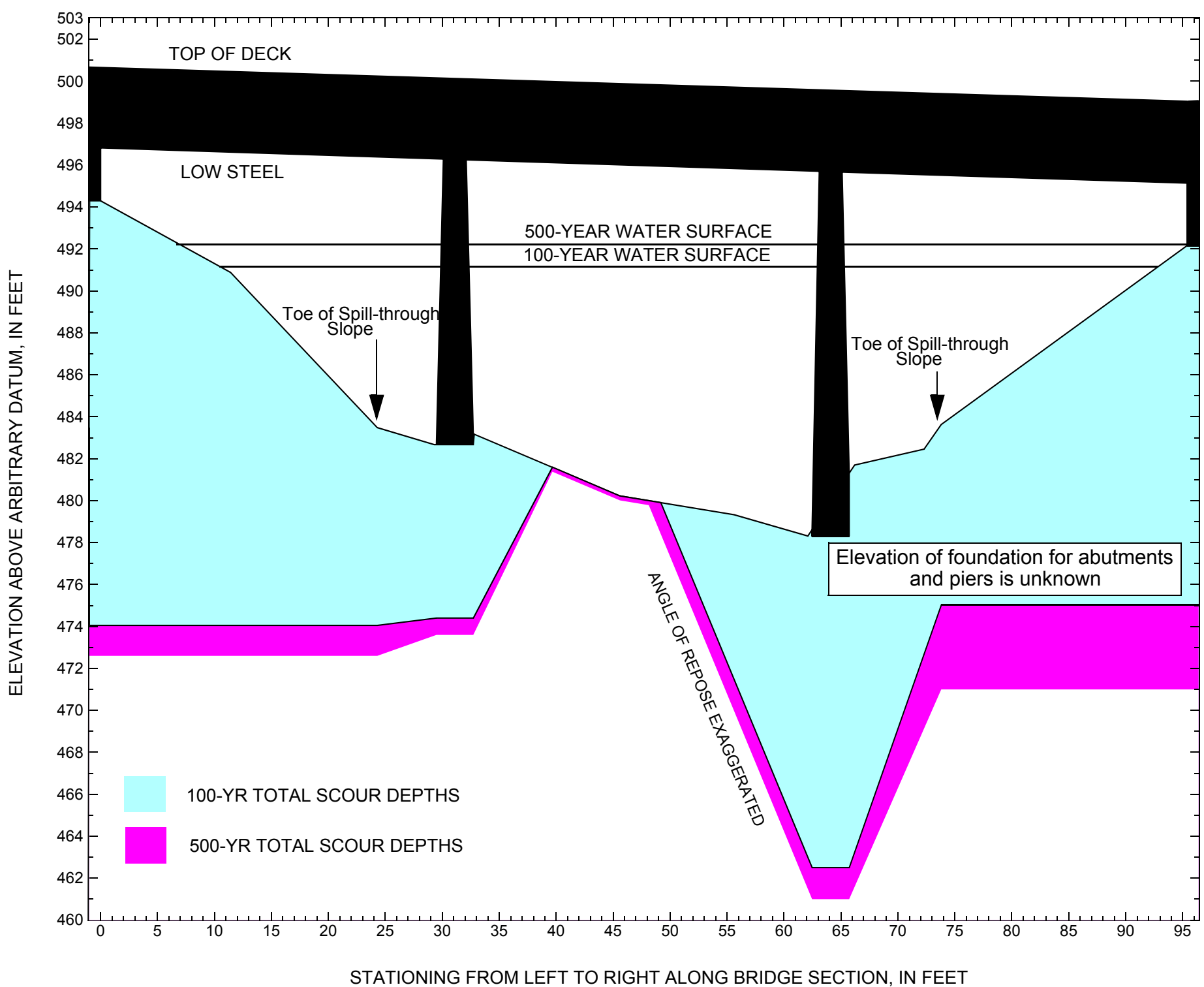

Figure 8. Scour elevations for the 100-yr and 500-yr discharges at structure CHESVT01030012 on State Route 103, crossing the Williams River, Chester, Vermont. 


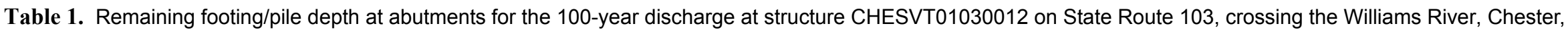
Vermont.

[VTAOT, Vermont Agency of Transportation; --,no data]

\begin{tabular}{|c|c|c|c|c|c|c|c|c|c|c|c|}
\hline Description & Station $^{1}$ & $\begin{array}{l}\text { VTAOT } \\
\text { minimum } \\
\text { low-chord } \\
\text { elevation } \\
\text { (feet) }\end{array}$ & $\begin{array}{c}\text { Surveyed } \\
\text { minimum } \\
\text { low-chord } \\
\text { elevation }{ }^{2} \\
\text { (feet) }\end{array}$ & $\begin{array}{l}\text { Bottom of } \\
\text { footing } \\
\text { elevation } \\
\text { (feet) }\end{array}$ & $\begin{array}{c}\text { Channel } \\
\text { elevation at } \\
\text { abutment/ } \\
\text { pier }^{2} \\
\text { (feet) }\end{array}$ & $\begin{array}{l}\text { Contraction } \\
\text { scour depth } \\
\text { (feet) }\end{array}$ & $\begin{array}{l}\text { Abutment } \\
\text { scour } \\
\text { depth } \\
\text { (feet) }\end{array}$ & $\begin{array}{l}\text { Pier } \\
\text { scour } \\
\text { depth } \\
\text { (feet) }\end{array}$ & $\begin{array}{l}\text { Depth of } \\
\text { total scour } \\
\text { (feet) }\end{array}$ & $\begin{array}{c}\text { Elevation of } \\
\text { scour }^{2} \\
\text { (feet) }\end{array}$ & $\begin{array}{c}\text { Remaining } \\
\text { footing/pile } \\
\text { depth } \\
\text { (feet) }\end{array}$ \\
\hline
\end{tabular}

\begin{tabular}{|c|c|c|c|c|c|c|c|c|c|c|c|}
\hline \multicolumn{12}{|c|}{100 -yr. discharge is 5,200 cubic-feet per second } \\
\hline Left abutment & 0.0 & - & 496.8 & - & 494.3 & 0.0 & - & -- & - & - & - \\
\hline Toe of LABUT & 24.3 & - & - & - & 483.5 & 0.0 & 9.4 & - & 9.4 & 474.1 & - \\
\hline Pier 1 & 31.1 & - & 496.1 & - & 482.7 & 0.0 & - & 8.3 & 8.3 & 474.4 & - \\
\hline Pier 2 & 64.1 & - & 495.8 & - & 478.3 & 0.0 & - & 15.8 & 15.8 & 462.5 & - \\
\hline Toe of RABUT & 73.8 & - & - & - & 483.6 & 0.0 & 8.6 & - & 8.6 & 475.0 & - \\
\hline Right abutment & 95.4 & - & 495.1 & - & 492.2 & 0.0 & - & -- & - & - & - \\
\hline
\end{tabular}

1.Measured along the face of the most constricting side of the bridge.

2.Arbitrary datum for this study.

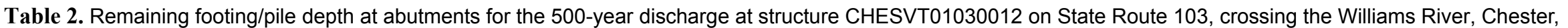
Vermont.

[VTAOT, Vermont Agency of Transportation; --, no data]

\begin{tabular}{|c|c|c|c|c|c|c|c|c|c|c|c|}
\hline Description & Station $^{1}$ & $\begin{array}{l}\text { VTAOT } \\
\text { minimum } \\
\text { low-chord } \\
\text { elevation } \\
\text { (feet) }\end{array}$ & $\begin{array}{l}\text { Surveyed } \\
\text { minimum } \\
\text { low-chord } \\
\text { elevation } \\
\text { (feet) }\end{array}$ & $\begin{array}{l}\text { Bottom of } \\
\text { footing } \\
\text { elevation } \\
\text { (feet) }\end{array}$ & $\begin{array}{c}\text { Channel } \\
\text { elevation at } \\
\text { abutment/ } \\
\text { pier }^{2} \\
\text { (feet) }\end{array}$ & $\begin{array}{l}\text { Contraction } \\
\text { scour depth } \\
\text { (feet) }\end{array}$ & $\begin{array}{l}\text { Abutment } \\
\text { scour } \\
\text { depth } \\
\text { (feet) }\end{array}$ & $\begin{array}{l}\text { Pier } \\
\text { scour } \\
\text { depth } \\
\text { (feet) }\end{array}$ & $\begin{array}{l}\text { Depth of } \\
\text { total scour } \\
\text { (feet) }\end{array}$ & $\begin{array}{c}\text { Elevation of } \\
\text { scour }^{2} \\
\text { (feet) }\end{array}$ & $\begin{array}{c}\text { Remaining } \\
\text { footing/pile } \\
\text { depth } \\
\text { (feet) }\end{array}$ \\
\hline \multicolumn{12}{|c|}{500 -yr. discharge is 7,620 cubic-feet per second } \\
\hline Left abutment & 0.0 & - & 496.8 & - & 494.3 & 0.2 & - & -- & - & - & - \\
\hline Toe of LABUT & 24.3 & - & - & - & 483.5 & 0.2 & 10.7 & - & 10.9 & 472.6 & - \\
\hline Pier 1 & 31.1 & - & 496.1 & - & 482.7 & 0.2 & - & 8.9 & 9.1 & 473.6 & - \\
\hline Pier 2 & 64.1 & - & 495.8 & - & 478.3 & 0.2 & - & 17.1 & 17.3 & 461.0 & - \\
\hline Toe of RABUT & 73.8 & - & - & - & 483.6 & 0.2 & 12.4 & - & 12.6 & 471.0 & - \\
\hline Right abutment & 95.4 & - & 495.1 & - & 492.2 & 0.2 & - & -- & - & - & - \\
\hline
\end{tabular}

1.Measured along the face of the most constricting side of the bridge.

2.Arbitrary datum for this study. 


\section{SELECTED REFERENCES}

Arcement, G.J., Jr., and Schneider, V.R., 1989, Guide for selecting Manning's roughness coefficients for natural channels and flood plains:

U.S. Geological Survey Water-Supply Paper 2339, 38 p.

Barnes, H.H., Jr., 1967, Roughness characteristics of natural channels: U.S. Geological Survey Water-Supply Paper 1849,213 p.

Benson, M. A., 1962, Factors Influencing the Occurrence of Floods in a Humid Region of Diverse Terrain: U.S. Geological Survey WaterSupply Paper 1580-B, 64 p.

Brown, S.A. and Clyde, E.S., 1989, Design of riprap revetment: Federal Highway Administration Hydraulic Engineering Circular No. 11, Publication FHWA-IP-89-016, 156 p.

Federal Highway Administration, 1983, Runoff estimates for small watersheds and development of sound design: Federal Highway Administration Report FHWA-RD-77-158.

Federal Highway Administration, 1993, Stream Stability and Scour at Highway Bridges: Participant Workbook: Federal Highway Administration Report FHWA-HI-91-011.

Federal Emergency Management Agency, 1982, Flood Insurance Study, Town of Chester, Windsor County, Vermont: Washington, D.C., Febrary 1982.

Froehlich, D.C., 1989, Local scour at bridge abutments in Ports, M.A., ed., Hydraulic Engineering--Proceedings of the 1989 National Conference on Hydraulic Engineering: New York, American Society of Civil Engineers, p. 13-18.

Hayes, D.C.,1993, Site selection and collection of bridge-scour data in Delaware, Maryland, and Virginia: U.S. Geological Survey WaterResources Investigation Report 93-4017, 23 p.

Interagency Advisory Committee on Water Data, 1982, Guidelines for determining flood flow frequency: U.S. Geological Survey, Bulletin 17B of the Hydrology Subcommittee, 190 p.

Johnson, C.G. and Tasker, G.D.,1974, Progress report on flood magnitude and frequency of Vermont streams: U.S. Geological Survey OpenFile Report 74-130, 37 p.

Lagasse, P.F., Schall, J.D., Johnson, F., Richardson, E.V., Chang, F., 1995, Stream Stability at Highway Structures: Federal Highway Administration Hydraulic Engineering Circular No. 20, Publication FHWA-IP-90-014, 144 p.

Laursen, E.M., 1960, Scour at bridge crossings: Journal of the Hydraulics Division, American Society of Civil Engineers, v. 86, no. HY2, p. 39-53.

Potter, W. D., 1957a, Peak rates of runoff in the Adirondack, White Mountains, and Maine woods area, Bureau of Public Roads

Potter, W. D., 1957b, Peak rates of runoff in the New England Hill and Lowland area, Bureau of Public Roads

Richardson, E.V. and Davis, S.R., 1995, Evaluating scour at bridges: Federal Highway Administration Hydraulic Engineering Circular No. 18, Publication FHWA-IP-90-017, 204 p.

Richardson, E.V., Simons, D.B., and Julien, P.Y., 1990, Highways in the river environment: Federal Highway Administration Publication FHWA-HI-90-016.

Ritter, D.F., 1984, Process Geomorphology: W.C. Brown Co., Debuque, Iowa, 603 p.

Shearman, J.O., 1990, User's manual for WSPRO--a computer model for water surface profile computations: Federal Highway Administration Publication FHWA-IP-89-027, 187 p.

Shearman, J.O., Kirby, W.H., Schneider, V.R., and Flippo, H.N., 1986, Bridge waterways analysis model; research report: Federal Highway Administration Publication FHWA-RD-86-108, 112 p.

Talbot, A.N., 1887, The determination of water-way for bridges and culverts.

U.S. Department of Transportation, 1993, Stream stability and scour at highway bridges, Participant Workbook: Federal Highway Administration Publication FHWA HI-91-011.

U.S. Geological Survey, 1972, Chester, Vermont 7.5 Minute Series quadrangle map: U.S. Geological Survey Topographic Maps, Scale $1: 24,000$. 


\section{APPENDIX A: \\ WSPRO INPUT FILE}




\section{WSPRO INPUT FILE}

GR

GR

GR

CD

$\mathrm{N}$

$\mathrm{XR}$

GR

GR

GR

GR

$\mathrm{XT}$

GR

GR

GR

GR

GR

GR

GT

$\mathrm{N}$

SA

*

*

*

XS

GR

GR

GR

GR

GR

$\mathrm{N}$

SA

U.S. Geological Survey WSPRO Input File ches012.wsp Hydraulic analysis for structure CHESVT01030012 Date: 13-MAR-97 Bridge \#12 over the Williams River, Chester, Vt. RHF

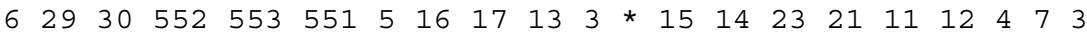

The following bridge is Bridge \#63 just downstream of the bridge of interest.

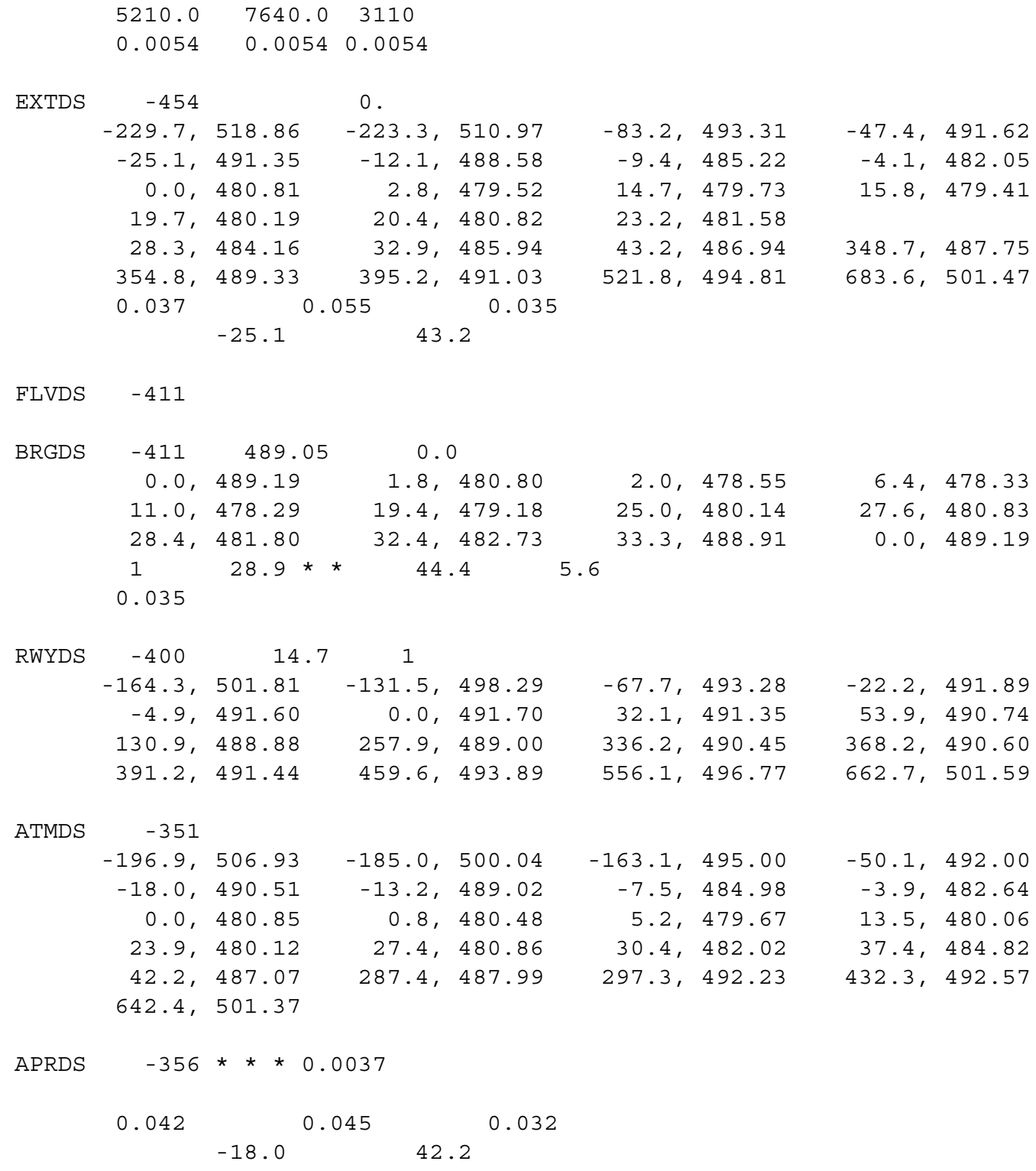

The following reach includes Bridge \#12. Discharge is decreased due to a slight change in the drainage area.

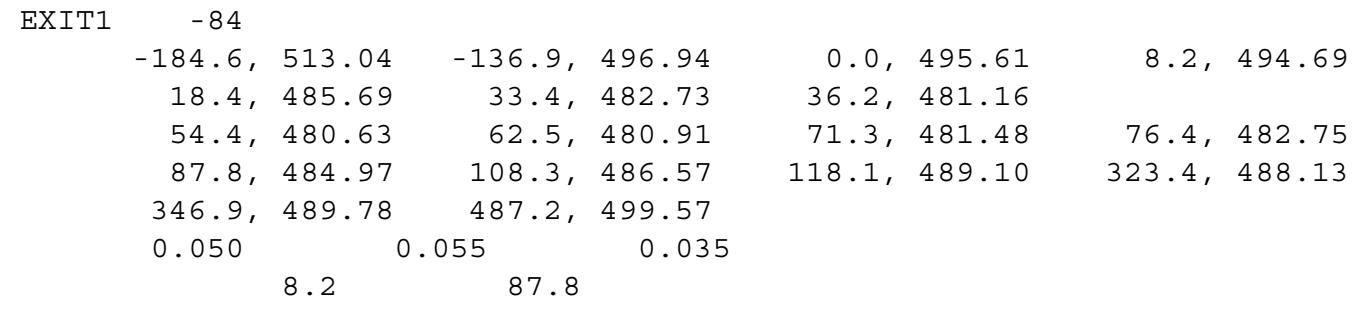

$0.0,495.61$

$36.2,481.16$

$71.3,481.48$

$118.1,489.10$

$76.4,482.75$

$323.4,488.13$ 


\section{WSPRO INPUT FILE (continued)}

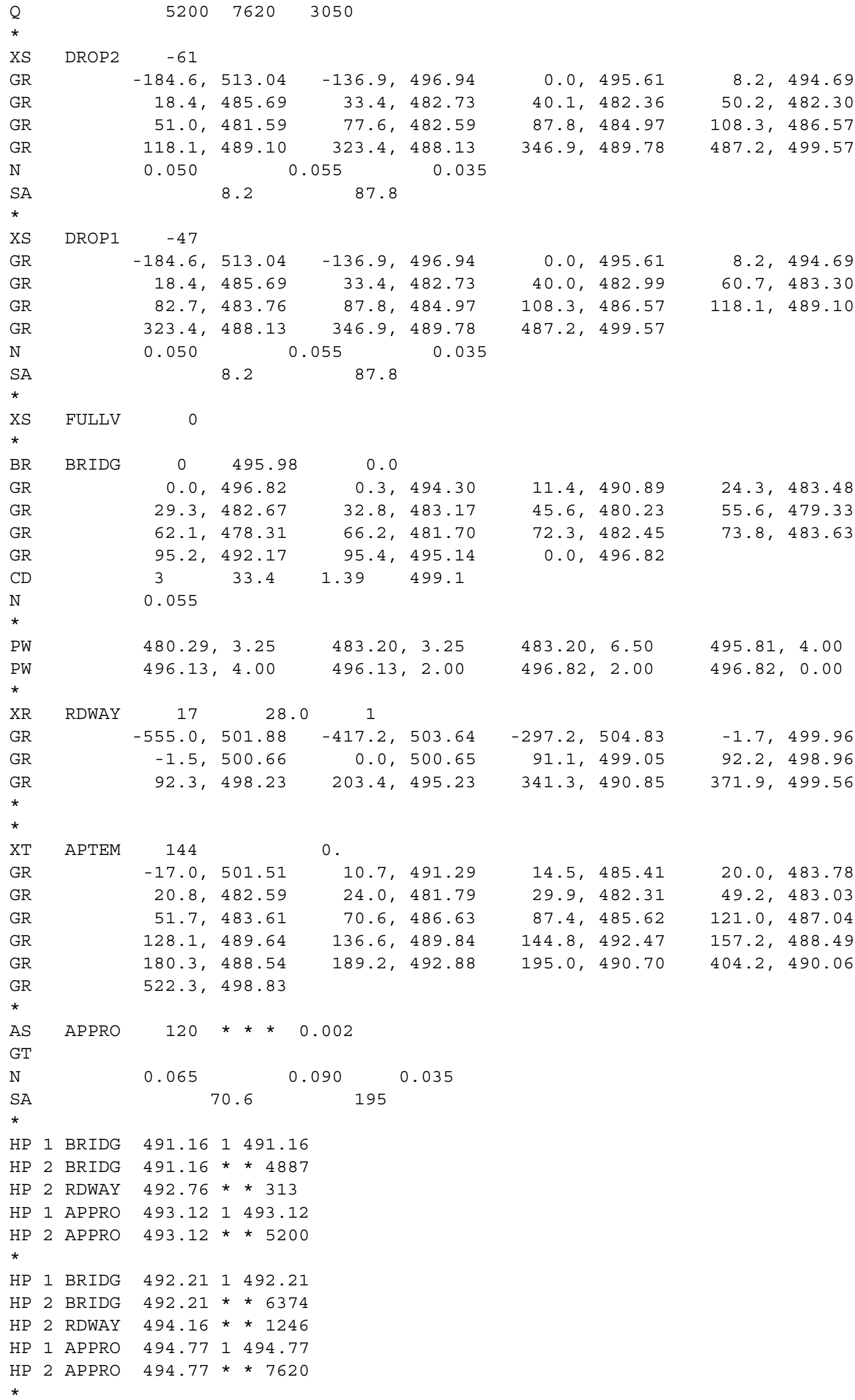




\section{APPENDIX B: \\ WSPRO OUTPUT FILE}




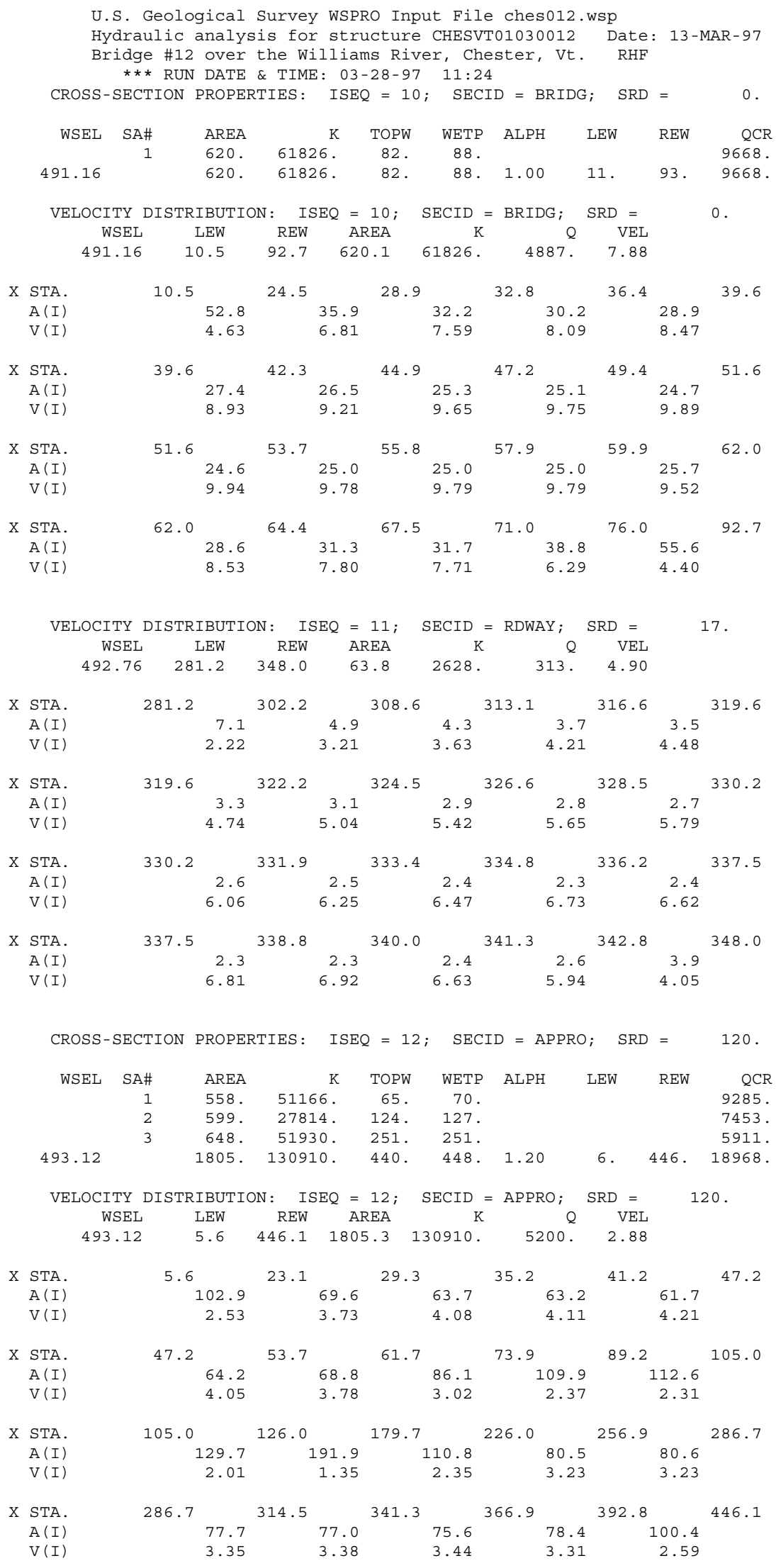




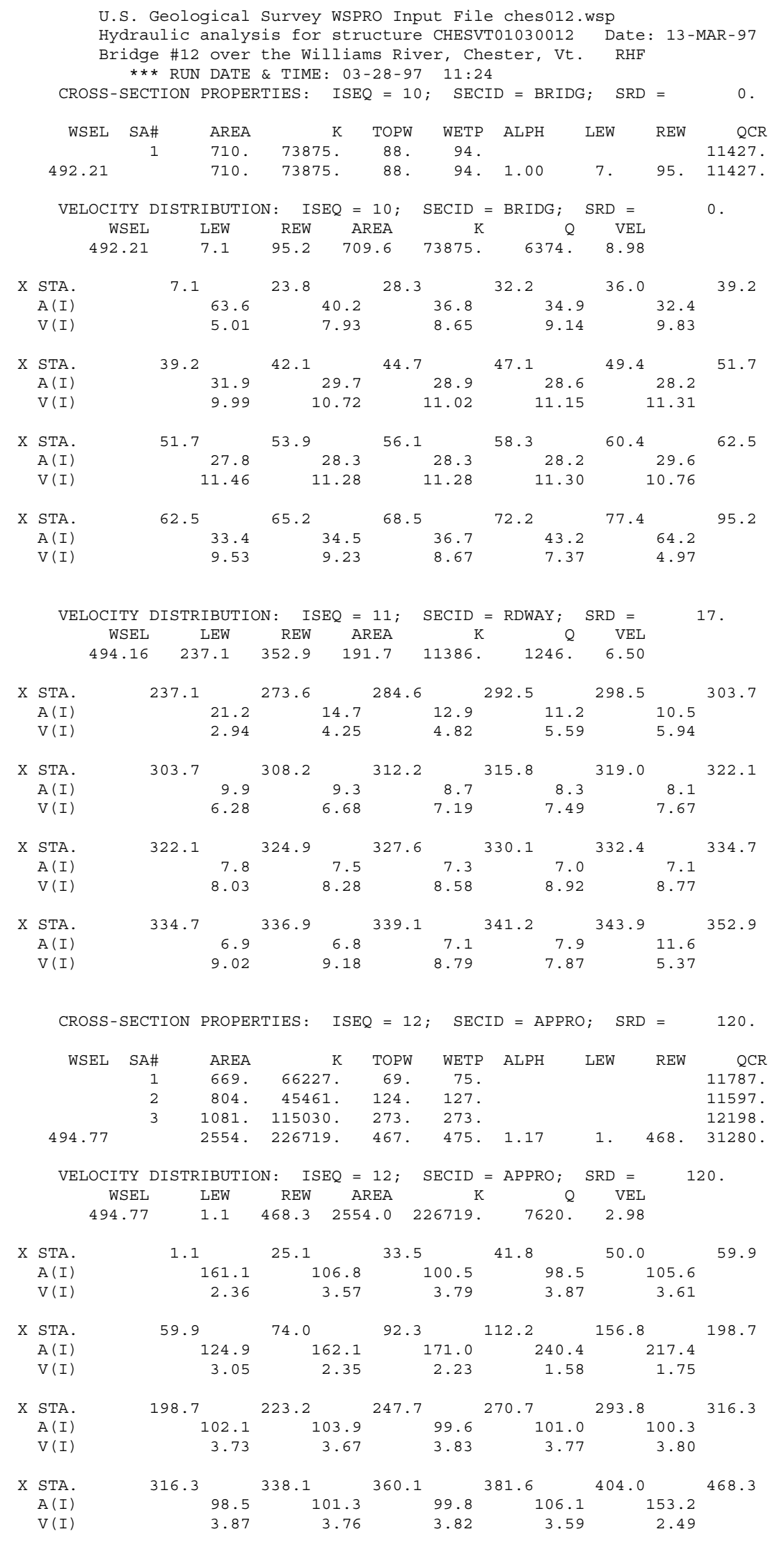


WSPRO OUTPUT FILE (continued)

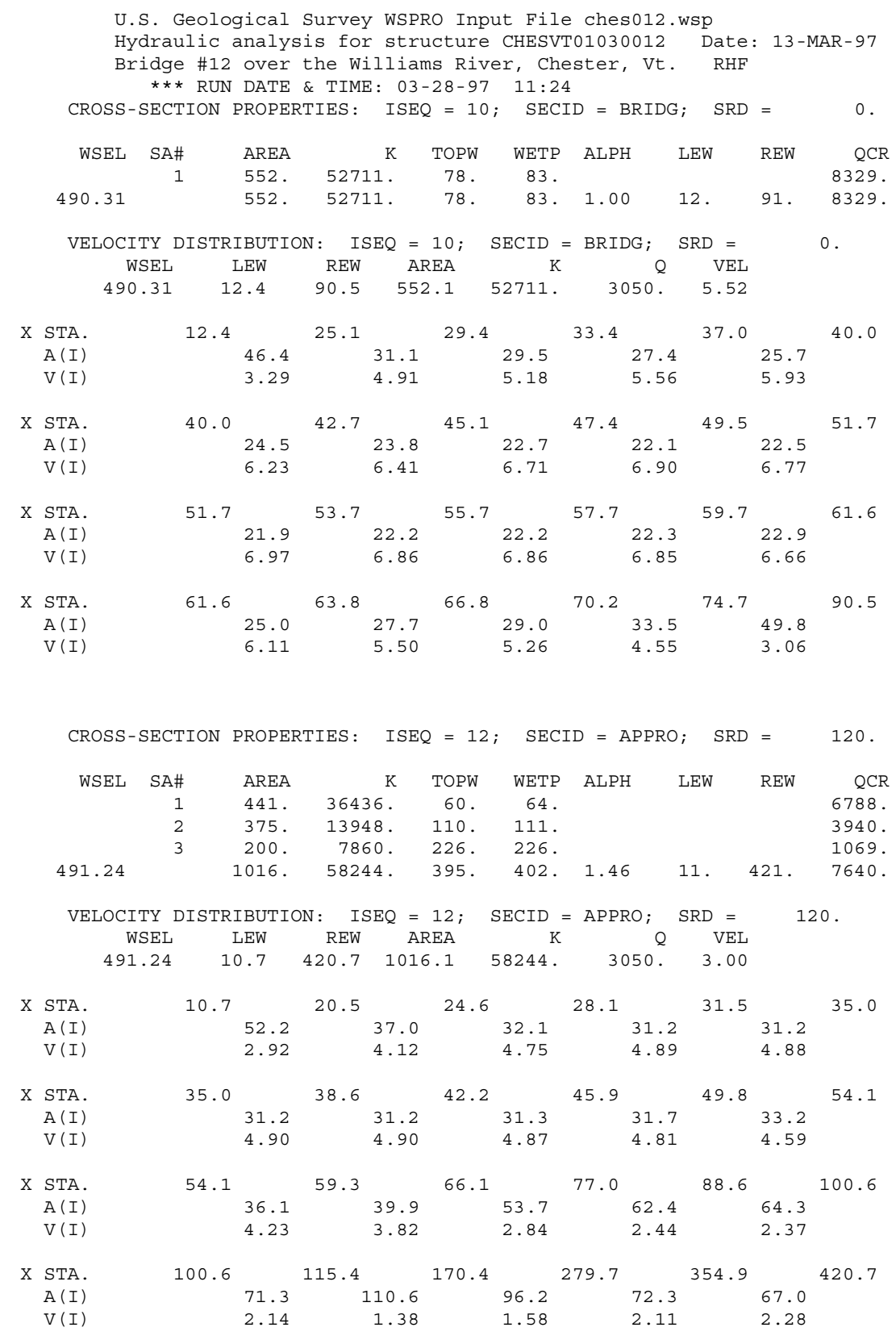


* HP records below are for upstream conditions using

* Q100, Q500 and incipient WSEL @ Bridge plus value of Ho at Appro.

CROSS-SECTION PROPERTIES: ISEQ $=10 ;$ SECID = BRIDG; $\operatorname{SRD}=\quad 0$.

\begin{tabular}{|c|c|c|c|c|c|c|c|c|c|c|c|}
\hline & WSEL & A\# & AREA & & K & TOPW & WETP & $\mathrm{ALPH}$ & LEW & REW & QCR \\
\hline & & 1 & 642. & 6467 & & 84. & 89. & & & & 10085 . \\
\hline & 491.42 & & 642. & 6467 & 2. & 84 . & 89. & 1.00 & 10. & 93. & 10085 . \\
\hline & VELOCITY & DISTR & IBUTIO & IS & $\mathrm{EQ}=$ & $10 ;$ & SECID = & : BRIDG; & $\mathrm{SRD}=$ & & 0 . \\
\hline & WSEL & & LEW & REW & & $\mathrm{REA}$ & $\mathrm{K}$ & Q & VEL & & \\
\hline & 491.42 & & 9.7 & 93.3 & 641 & 1.7 & 64672 . & 4887. & 7.62 & & \\
\hline $\mathrm{x}$ & STA. & 9.7 & & 24.4 & & 28.8 & & 32.7 & 36.3 & & 39.4 \\
\hline & $A(I)$ & & 56.1 & & 36.2 & & 33.5 & 31.3 & & 29.3 & \\
\hline & $V(I)$ & & 4.36 & & 6.75 & & 7.29 & 7.81 & & 8.35 & \\
\hline $\mathrm{x}$ & STA. & 39.4 & & 42.3 & & 44.8 & & 47.2 & 49.4 & & 51.6 \\
\hline & $A(I)$ & & 28.9 & & 27.4 & & 26.1 & 25.8 & & 25.5 & \\
\hline & $V(I)$ & & 8.47 & & 8.93 & & 9.35 & 9.46 & & 9.59 & \\
\hline $\mathrm{x}$ & STA. & 51.6 & & 53.8 & & 55.9 & & 58.0 & 60.1 & & 62.1 \\
\hline & $A(I)$ & & 25.4 & & 25.8 & & 25.8 & 25.8 & & 26.5 & \\
\hline & $V(I)$ & & 9.62 & & 9.47 & & 9.47 & 9.47 & & 9.22 & \\
\hline $\mathrm{x}$ & STA. & 62.1 & & 64.6 & & 67.8 & & 71.4 & 76.4 & & 93.3 \\
\hline & $A(I)$ & & 30.0 & & 32.3 & & 33.0 & 39.9 & & 57.3 & \\
\hline & $V(I)$ & & 8.15 & & 7.57 & & 7.41 & 6.12 & & 4.27 & \\
\hline
\end{tabular}

$\begin{array}{rrrrrrrrrr}\text { WSEL } & \text { SA\# } & \text { AREA } & \text { K } & \text { TOPW } & \text { WETP } & \text { ALPH } & \text { LEW } & \text { REW } & \text { QCR } \\ & 1 & 735 . & 77685 . & 89 . & 95 . & & & & 11988 . \\ 492.50 & & 735 . & 77685 . & 89 . & 95 . & 1.00 & 6 . & 95 . & 11988 .\end{array}$

VELOCITY DISTRIBUTION: ISEQ $=10 ; \quad \operatorname{SECID}=$ BRIDG; $\quad \mathrm{SRD}=0$.

$\begin{array}{rrrrrrr}\text { WSEL } & \text { LEW } & \text { REW } & \text { AREA } & \text { K } & \text { Q } & \text { VEL } \\ 492.50 & 6.2 & 95.2 & 735.3 & 77685 . & 6374 . & 8.67\end{array}$

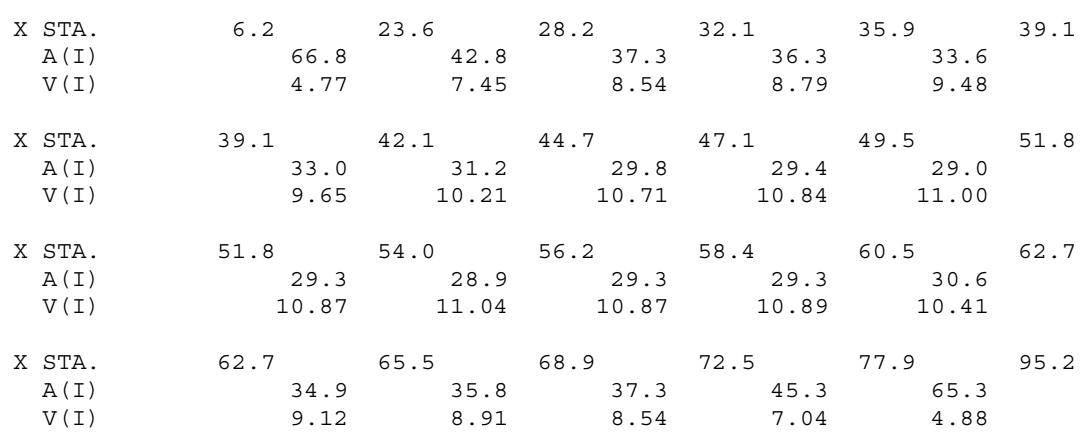

CROSS-SECTION PROPERTIES: ISEQ $=10 ;$ SECID $=$ BRIDG $; \quad$ SRD $=\quad 0$.

$\begin{array}{rrlrrrrrrr}\text { WSEL } & \text { SA\# } & \text { AREA } & \text { K } & \text { TOPW } & \text { WETP } & \text { ALPH } & \text { LEW } & \text { REW } & \text { QCR } \\ & 1 & 564 . & 54291 . & 79 . & 84 . & & & & 8562 . \\ 490.46 & & 564 . & 54291 & 79 . & 84 . & 1.00 & 12 . & 91.8562 .\end{array}$

VELOCITY DISTRIBUTION: ISEQ $=10 ; \quad \operatorname{SECID}=$ BRIDG $; \quad \mathrm{SRD}=\quad 0$.

$\begin{array}{ccccc}\text { WSEL LEW REW AREA } & K & Q & \text { VEL }\end{array}$

$\begin{array}{llllll}490.46 & 12.1 & 90.9 & 563.9 & 54291 . & 3050 .\end{array}$

\begin{tabular}{|c|c|c|c|c|c|c|c|c|c|}
\hline \multirow[t]{3}{*}{$\mathrm{X}$} & STA. & 12.1 & 25.1 & & 29.3 & 33.3 & & 36.9 & 39.9 \\
\hline & $A(I)$ & 48.1 & & 30.9 & 30.3 & & 28.0 & \multicolumn{2}{|c|}{25.7} \\
\hline & $V(I)$ & 3.17 & & 4.94 & 5.04 & & 5.44 & \multicolumn{2}{|c|}{5.93} \\
\hline \multirow[t]{3}{*}{$\mathrm{X}$} & STA. & 39.9 & \multirow[t]{3}{*}{42.6} & & 45.1 & \multirow[t]{3}{*}{47.3} & & 49.5 & \multirow[t]{3}{*}{51.6} \\
\hline & $A(I)$ & 25.5 & & 24.2 & 23.1 & & 22.5 & & \\
\hline & $V(I)$ & 5.98 & & 6.29 & 6.59 & & 6.77 & & \\
\hline \multirow[t]{3}{*}{$\mathrm{X}$} & STA. & 51.6 & \multirow[t]{3}{*}{53.7} & & 55.8 & \multirow[t]{3}{*}{57.8} & & 59.7 & \multirow[t]{3}{*}{61.7} \\
\hline & $A(I)$ & 22.3 & & 22.7 & 22.7 & & 22.7 & & \\
\hline & $V(I)$ & 6.84 & & 6.73 & 6.73 & & 6.72 & & \\
\hline \multirow[t]{3}{*}{$\mathrm{X}$} & STA. & 61.7 & 63.9 & & 66.9 & 70.4 & & 75.0 & \multirow[t]{3}{*}{90.9} \\
\hline & $\mathrm{A}(\mathrm{I})$ & 26.0 & & 28.2 & 29.8 & & 34.2 & & \\
\hline & $\mathrm{V}(\mathrm{I})$ & 5.87 & & 5.41 & 5.13 & & 4.46 & & \\
\hline
\end{tabular}


WSPRO OUTPUT FILE (continued)

WSPRO FEDERAL HIGHWAY ADMINISTRATION - U. S. GEOLOGICAL SURVEY

V090192 MODEL FOR WATER-SURFACE PROFILE COMPUTATIONS

U.S. Geological Survey WSPRO Input File ches012.wsp

Hydraulic analysis for structure CHESVT01030012 Date: 13-MAR-97

Bridge \#12 over the Williams River, Chester, Vt. RHF

*** RUN DATE \& TIME: 03-28-97 11:24

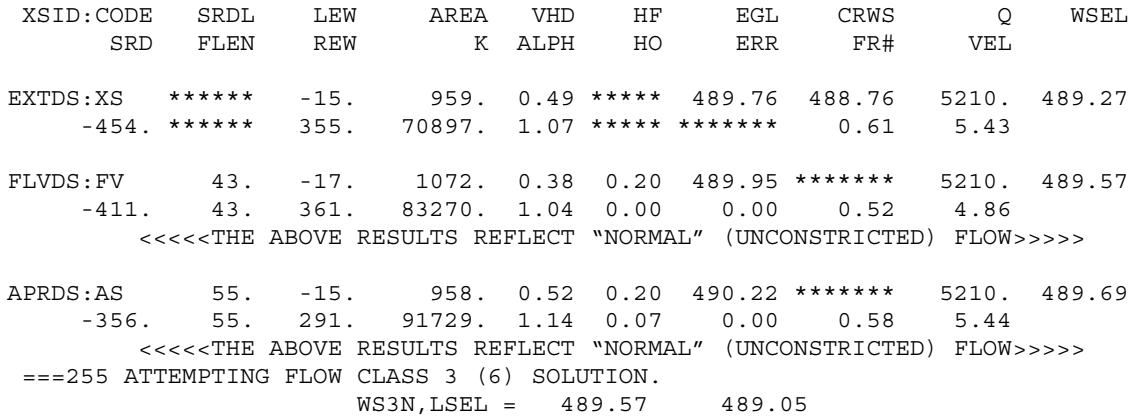




\section{WSPRO OUTPUT FILE (continued)}

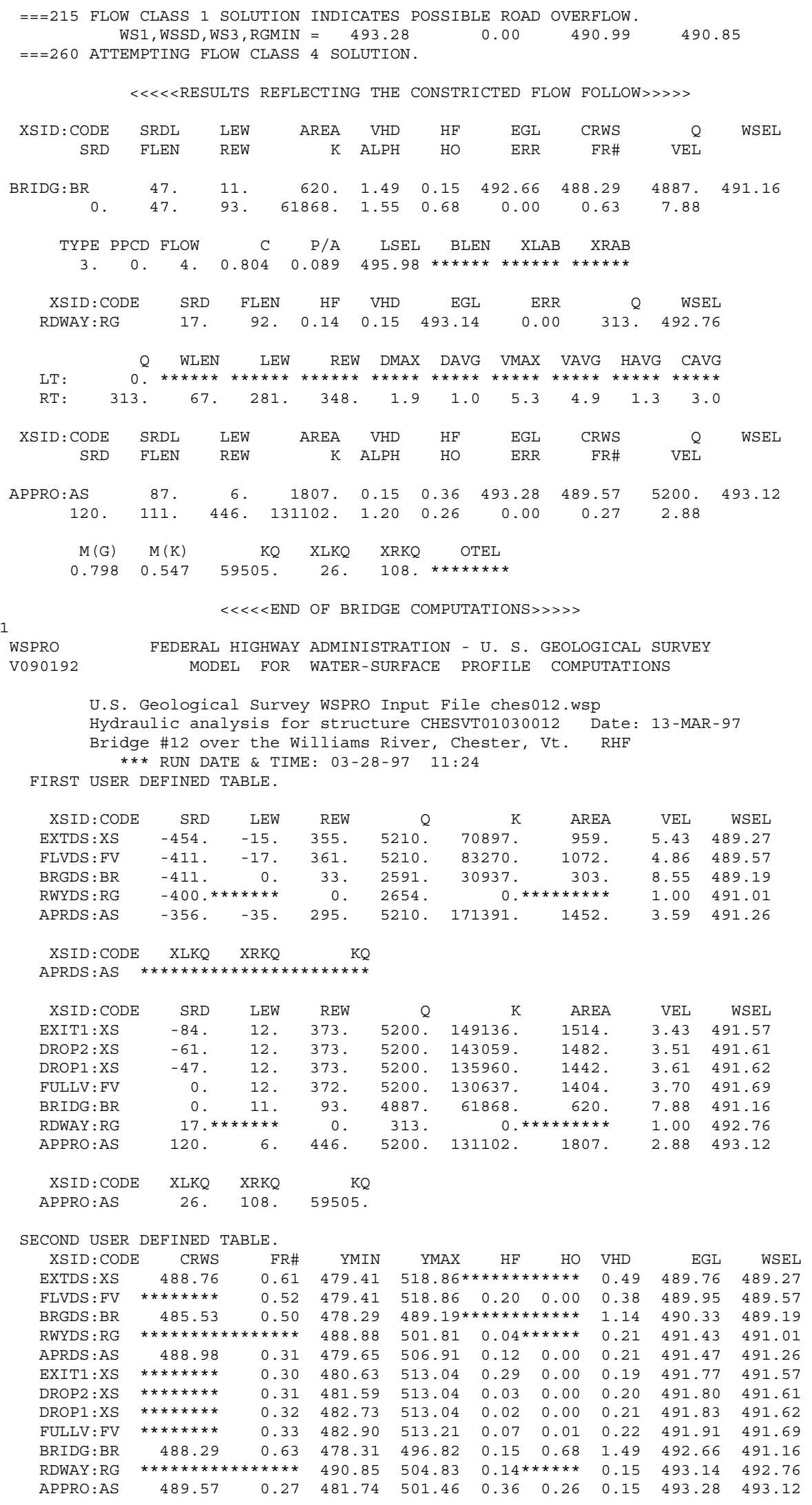


WSPRO OUTPUT FILE (continued)

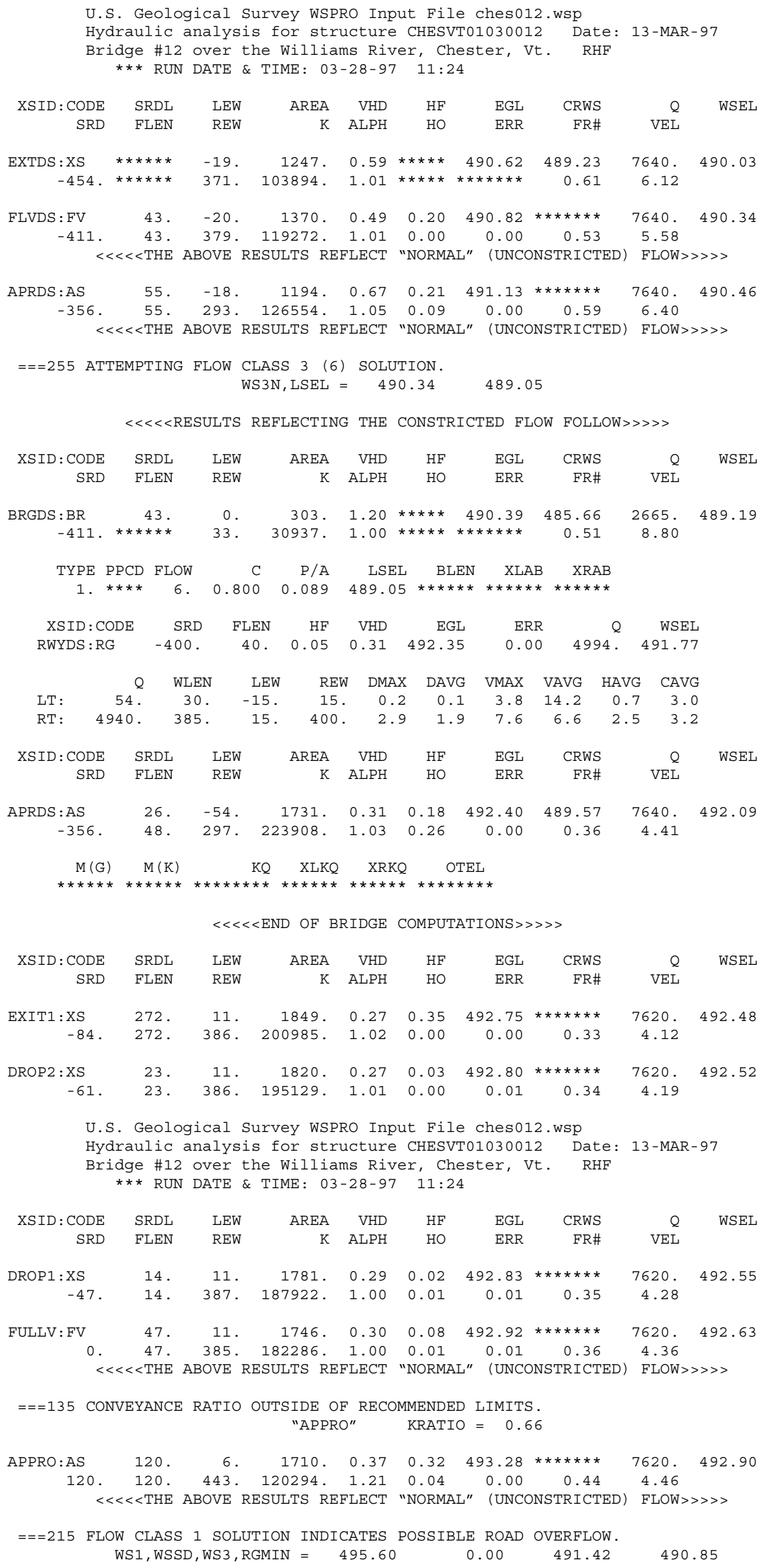




\section{WSPRO OUTPUT FILE (continued)}

$===260$ ATTEMPTING FLOW CLASS 4 SOLUTION.

$\ll<<<$ RESULTS REFLECTING THE CONSTRICTED FLOW FOLLOW $\gg>>>$

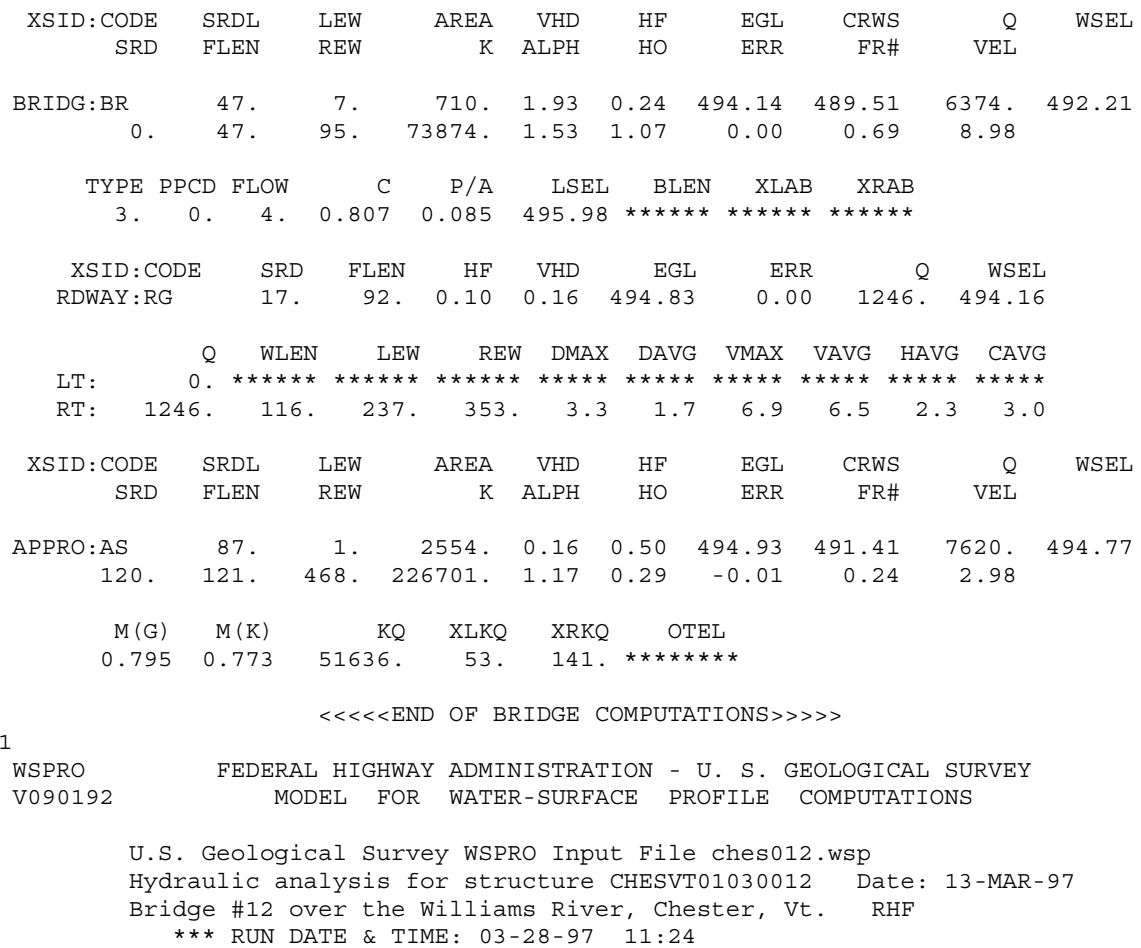

\begin{tabular}{|c|c|c|c|c|c|c|c|c|c|}
\hline XSID : CODE & CRWS & FR\# & YMIN & YMAX & $\mathrm{HF}$ & $\mathrm{HO}$ & VHD & EGL & WSEL \\
\hline EXTDS:XS & 489.23 & 0.61 & 479.41 & $518.86 * *$ & $* * * * * * *$ & $* \star \star * *$ & 0.59 & 490.62 & 490.03 \\
\hline FLVDS : FV & 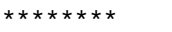 & 0.53 & 479.41 & 518.86 & 0.20 & 0.00 & 0.49 & 490.82 & 490.34 \\
\hline BRGDS : BR & 485.66 & 0.51 & 478.29 & $489.19 * *$ & $* * * * * *$ & $* \star \star \star * *$ & 1.20 & 490.39 & 489.19 \\
\hline RWYDS : RG & $\star * \star * * * * *$ & $* \star \star \star \star *$ & 488.88 & 501.81 & $0.05 * *$ & $* \star \star \star * *$ & 0.31 & 492.35 & 491.77 \\
\hline APRDS: AS & 489.57 & 0.36 & 479.65 & 506.91 & 0.18 & 0.26 & 0.31 & 492.40 & 492.09 \\
\hline EXIT1:XS & $\star * \star * \star * \star * *$ & 0.33 & 480.63 & 513.04 & 0.35 & 0.00 & 0.27 & 492.75 & 492.48 \\
\hline DROP2: XS & 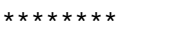 & 0.34 & 481.59 & 513.04 & 0.03 & 0.00 & 0.27 & 492.80 & 492.52 \\
\hline ROP1 : XS & 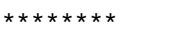 & 0.35 & 482.73 & 513.04 & 0.02 & 0.01 & 0.29 & 492.83 & 492.55 \\
\hline FULLV : FV & $\star \star \star \star \star \star \star \star * \star$ & 0.36 & 482.90 & 513.21 & 0.08 & 0.01 & 0.30 & 492.92 & 492.63 \\
\hline BRIDG : BR & 489.51 & 0.69 & 478.31 & 496.82 & 0.24 & 1.07 & 1.93 & 494.14 & 492.21 \\
\hline RDWAY : RG & 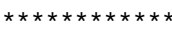 & 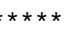 & 490.85 & 504.83 & 0.10 * & 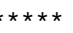 & 0.16 & 494.83 & 494.16 \\
\hline APPRO:AS & 491.41 & 0.24 & 481.74 & 501.46 & 0.50 & 0.29 & 0.16 & 494.93 & 494.77 \\
\hline
\end{tabular}


WSPRO OUTPUT FILE (continued)

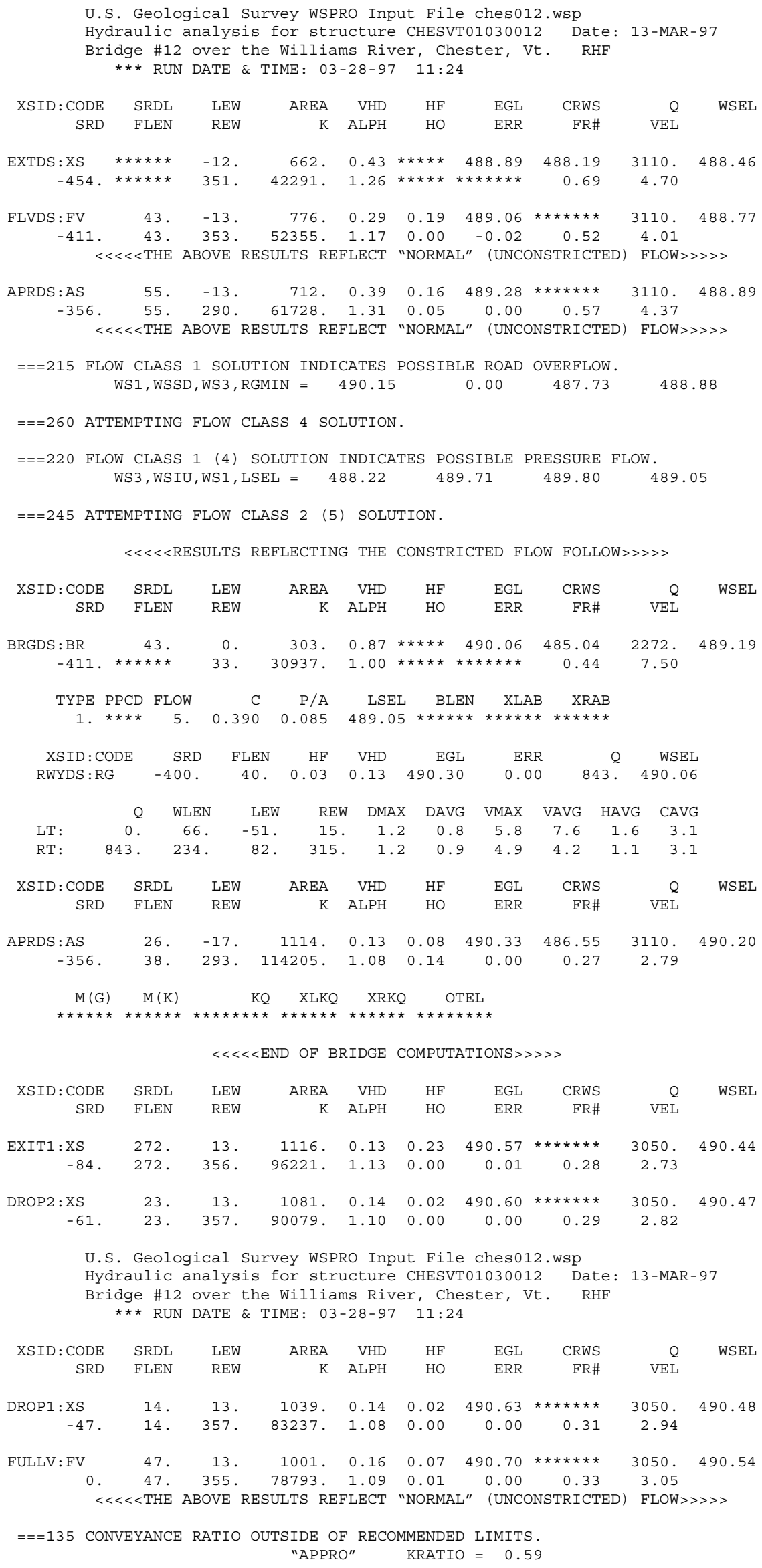


WSPRO OUTPUT FILE (continued)

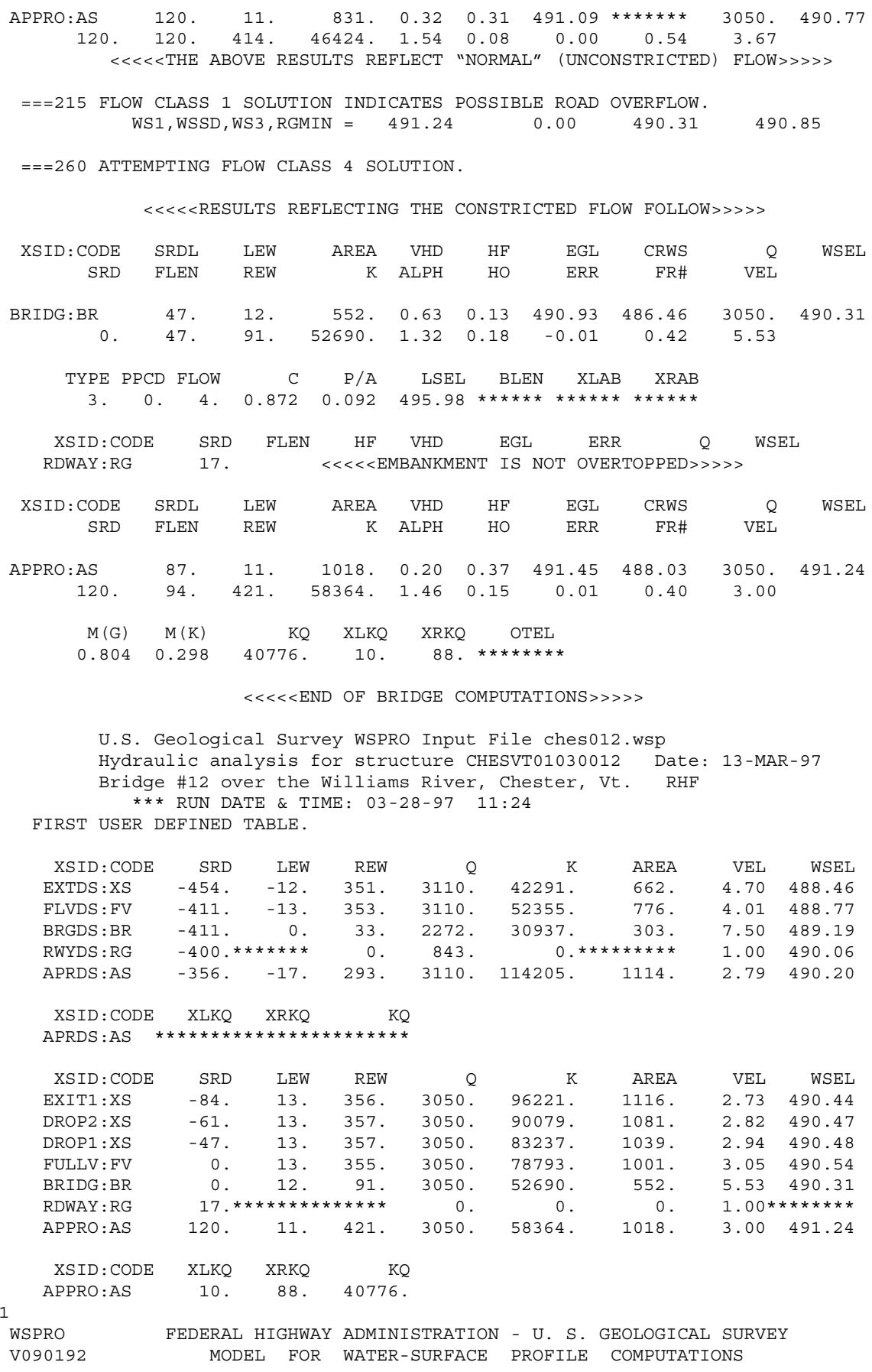

\begin{tabular}{|c|c|c|c|c|c|c|c|c|c|}
\hline XSID : CODE & CRWS & FR\# & YMIN & YMAX & $\mathrm{HF}$ & $\mathrm{HO}$ & VHD & EGL & WSEL \\
\hline EXTDS : XS & 488.19 & 0.69 & 479.41 & $518.86 * *$ & 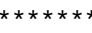 & 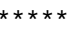 & 0.43 & 488.89 & 488.46 \\
\hline FLVDS : FV & 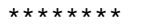 & 0.52 & 479.41 & 518.86 & 0.19 & 0.00 & 0.29 & 489.06 & 488.77 \\
\hline BRGDS : BR & 485.04 & 0.44 & 478.29 & $489.19 * *$ & $\star \star \star \star \star * \star * \star$ & 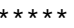 & 0.87 & 490.06 & 489.19 \\
\hline RWYDS : RG & $\star \star \star *$ & & 488.88 & 501.81 & 0.03 & 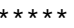 & 0.13 & .30 & 490.06 \\
\hline APRDS : AS & 486.55 & 0.27 & 479.65 & 506.91 & 0.08 & 0.14 & 0.13 & 490.33 & 490.20 \\
\hline EXIT1:XS & $\star * * * * * * *$ & 0.28 & 480.63 & 513.04 & 0.23 & 0.00 & 0.13 & 490.57 & 490.44 \\
\hline DROP2 : XS & 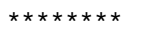 & 0.29 & 481.59 & 513.04 & 0.02 & 0.00 & 0.14 & 490.60 & 490.47 \\
\hline DROP1 : XS & $\star \star \star \star \star \star \star \star * *$ & 0.31 & 482.73 & 513.04 & 0.02 & 0.00 & 0.14 & 490.63 & 490.48 \\
\hline FULLV : FV & 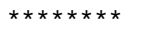 & 0.33 & 482.90 & 513.21 & 0.07 & 0.01 & 0.16 & 490.70 & 490.54 \\
\hline BRIDG : BR & 486.46 & 0.42 & 478.31 & 496.82 & 0.13 & 0.18 & 0.63 & 490.93 & 490.31 \\
\hline RDWAY : RG & 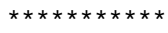 & $\star \star \star * *$ & 490.85 & 504.83 & $0.25 * *$ & 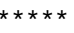 & 0.20 & 491.20 * & 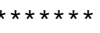 \\
\hline APPRO: AS & 488.03 & 0.40 & 481.74 & 501.46 & 0.37 & 0.15 & 0.20 & 491.45 & 491.24 \\
\hline
\end{tabular}




\section{APPENDIX C:}

\section{BED-MATERIAL PARTICLE-SIZE DISTRIBUTION}




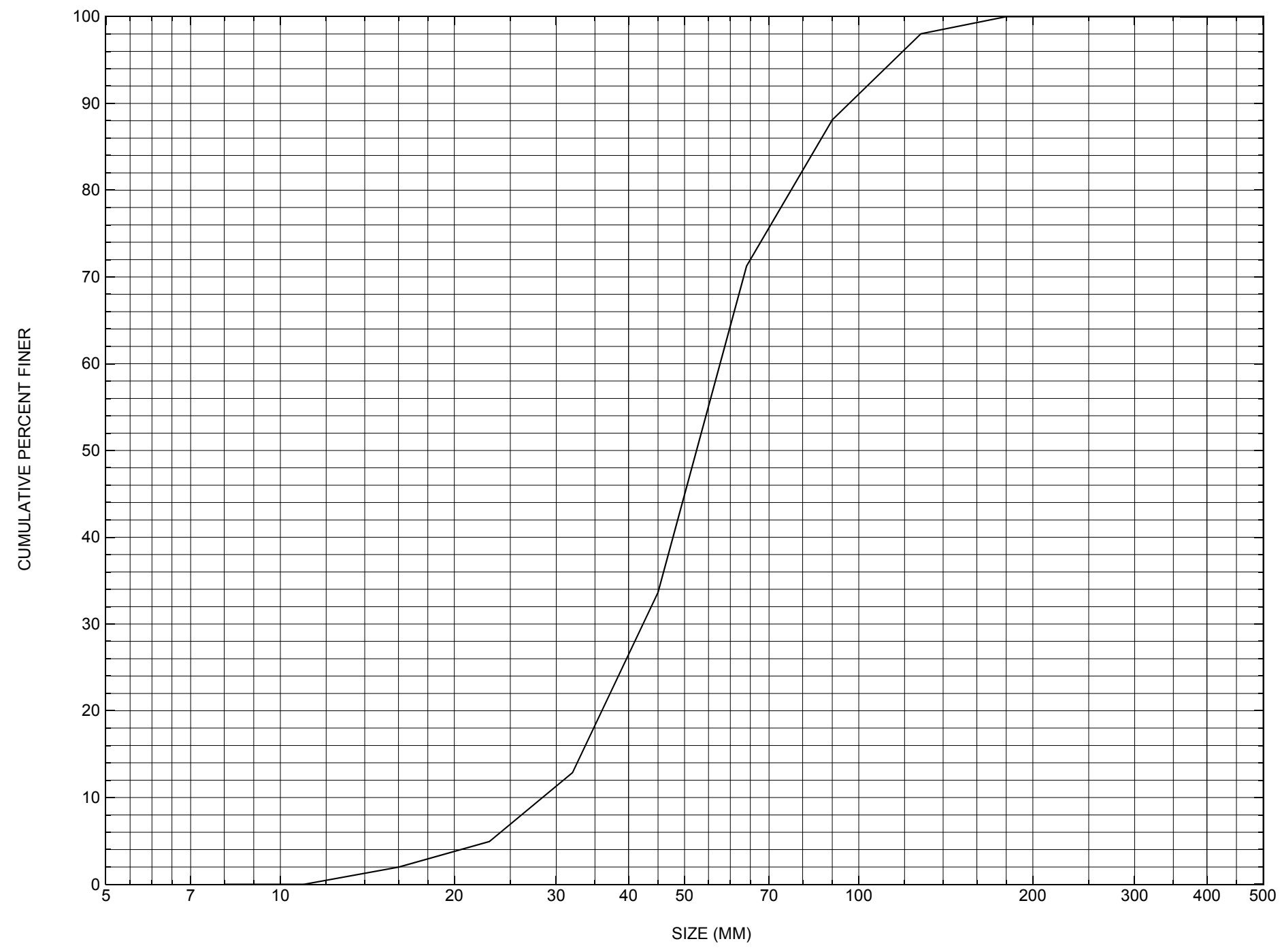

Appendix C. Bed material particle-size distribution for a pebble count in the channel approach of structure CHESVT01030012, in Chester, Vermont. 


\section{APPENDIX D: \\ HISTORICAL DATA FORM}




\section{Structure Number CHESVT01030012}

\section{General Location Descriptive}

Data collected by (First Initial, Full last name) $\mathbf{E}$. BOEHMLER

Date $(M M / D D / Y Y) \_\mathbf{0 3} / \underline{29} / \underline{95}$

Highway District Number (I - 2; nn) $\mathbf{0 2}$

Town (FIPS place code; I - 4; nnnnn) $\mathbf{1 3 6 0 0}$

Waterway (I - 6) WILLIAMS RIVER

Route Number VT103

Topographic Map Chester

Latitude (I - 16; nnnn.n) $\mathbf{4 3 1 6 3}$
County (FIPS county code; I - 3; nnn)

Mile marker (I - 11; nnn.nnn) $\mathbf{0 0 3 8 3 0}$

Road Name (I - 7): -

Vicinity (I - 9) 0.8 MI N JCT. VT.11 W

Hydrologic Unit Code: $\mathbf{0 1 0 8 0 1 0 7}$

Longitude (i - 17; nnnnn.n) $\mathbf{7 2 3 5 4}$

\section{Select Federal Inventory Codes}

FHWA Structure Number $(I$ - 8) $\mathbf{2 0 0 0 2 5 0 0 1 2 1 4 0 7}$

Maintenance responsibility $(I-21 ; n n) \quad \mathbf{0 3}$

Year built (I - 27; YYYY) 1931

Average daily traffic, ADT (I - 29; nnnnnn) $\underline{003443}$

Year of ADT (I - 30; YY) $\mathbf{9 2}$

Opening skew to Roadway $(I-34 ; n n) \quad \mathbf{0 0}$

Operational status $(I-41 ; X) \quad \mathbf{A}$

Structure type (I - 43; nnn) 104

Approach span structure type $(I-44 ; n n n)$ 000

Number of spans (I - 45; nnn) $\underline{\mathbf{0 0 3}}$

Number of approach spans (I - 46; nnnn) $\mathbf{0 0 0 0}$

Comments:

The structural inspection report of 11/18/93 indicates the structure is a three span, concrete T-beam type bridge. The report refers to a proposal to repair or replace the existing bridge. The latest memorandum for action is dated $03 / 08 / 94$. The wingwalls are short extensions of the abutment walls. Both piers are solid concrete and have some spalling at their ends. There is some minor reinforcement bar exposed in a few locations. The footings are not in view. The water is noted as quite deep along pier 1 on the north side. The waterway makes a sharp turn into the structure. The streambed consists of sand and gravel. The banks in front of the abutments are well protected with stone fill. (Continued, page 38) 


\section{Bridge Hydrologic Data}

Is there hydrologic data available? $\underline{\mathbf{Y}}$ if No, type ctrl-n $h \quad$ VTAOT Drainage area $\left(m i^{2}\right): \underline{\mathbf{2 7 . 0}}$

Terrain character:

Stream character \& type: -

Streambed material: SAND AND GRAVEL

Discharge Data (cfs): $\mathrm{Q}_{2.33} \underline{\mathbf{1 2 0 0}}$

$\mathrm{Q}_{50} \mathbf{4 8 0 0}$

\begin{tabular}{ll}
$Q_{10} \frac{\mathbf{3 0 0 0}}{\mathbf{5 6 0 0}}$ & $Q_{25} \stackrel{\mathbf{4 0 0 0}}{\mathrm{Q}_{100}} \mathrm{Q}_{500}-$ \\
\hline
\end{tabular}

Record flood date (MM/DD/YY): - $/$ - $/$ Water surface elevation $(f t):-$

Estimated Discharge (cfs): Velocity at $\mathrm{Q}-$ $(\mathrm{ft} / \mathrm{s}):$

Ice conditions (Heavy, Moderate, Light) : Debris (Heavy, Moderate, Light):

The stage increases to maximum highwater elevation (Rapidly, Not rapidly):

The stream response is (Flashy, Not flashy):

Describe any significant site conditions upstream or downstream that may influence the stream's stage: Downstream is a dam and grist mill.

Watershed storage area (in percent):

The watershed storage area is: - _ (1-mainly at the headwaters; 2- uniformly distributed; 3-immediatly upstream oi the site)

Water Surface Elevation Estimates for Existing Structure:

\begin{tabular}{|l|l|c|c|l|l|}
\hline Peak discharge frequency & $Q_{2.33}$ & $Q_{10}$ & $Q_{25}$ & $Q_{50}$ & $Q_{100}$ \\
Water surface elevation (ft)) & $\mathbf{5 8 6 . 6}$ & $\mathbf{5 8 9 . 5}$ & $\mathbf{5 9 0 . 7}$ & $\mathbf{5 9 1 . 6}$ & $\mathbf{5 9 3 . 5}$ \\
Velocity $(\mathrm{ft} / \mathrm{sec})$ & - & - & - & - & - \\
\hline
\end{tabular}

Long term stream bed changes: -

Is the roadway overtopped below the $\mathrm{Q}_{100}$ ? (Yes, No, Unknown): $\mathbf{Y} \quad$ Frequency: $\underline{\mathbf{Q 1 0}}$ Relief Elevation $(f t)$ :

Discharge over roadway at $\mathrm{Q}_{100}\left(f^{3} / \mathrm{sec}\right)$ : -

Are there other structures nearby? (Yes, No, Unknown): Y Upstream distance (miles): $\mathbf{3 0 0 0}$ ' Town: CHESTER If No or Unknown, type ctrl-n os Highway No. : $\mathbf{T H 0 0 5}$ Structure No. : 11 Year Built: 1940 Clear span (ft): $\underline{\mathbf{1 1 0}}$ Clear Height $(f t): \underline{\mathbf{1 4 . 0}}$ Full Waterway $\left(f t^{2}\right):$ 
Downstream distance (miles): $\underline{400}$ ' Town: CHESTER

Year Built:

Highway No. : TH 009

Structure No. : 63

Structure Type: STEEL BEAM

Clear span (ft): $\underline{\mathbf{3 1 . 0}}$ Clear Height $(f t): \underline{\mathbf{8 . 6}}$

Full Waterway $\left(f^{2}\right)$ :

Comments:

There is a small dam and grist mill just downstream. The existing beams are above the Q100, due to the roadway overflow on the south approach at about $Q 10$. The recommendation is for a 90' minimum clear span with the bottom of beams at or above $592.5(04 / 22 / 92)$. Bridge deck is highly deteriorated and given a rating of 2 out of 10 in the inspector's report. Cross-sections are available from FEMA data. The Vermont Agency of Transportation used WSPRO and the data is in the hydraulic folder. Proposed construction date 1995.

\section{USGS Watershed Data}

Watershed Hydrographic Data

Drainage area $(D A) \underline{23.94} \mathrm{mi}^{2}$ Lake and pond area $\underline{\mathbf{0 . 0 8}}$ $\mathrm{mi}^{2}$

Watershed storage (ST)

Bridge site elevation 600 0.3 $\%$

Main channel length 14.47 $\mathrm{ft}$

Headwater elevation 2882 $\mathrm{ft}$ $10 \%$ channel length elevation $\mathbf{6 2 0}$ $\mathrm{ft} \quad 85 \%$ channel length elevation 1580 $\mathrm{ft}$

Main channel slope (S) 88.45 $\mathrm{ft} / \mathrm{mi}$

Watershed Precipitation Data

Average site precipitation in Average headwater precipitation in

Maximum 2yr-24hr precipitation event $(124,2)$ in

Average seasonal snowfall (Sn) $\mathrm{ft}$ 


\section{Bridge Plan Data}

Are plans available? $\mathbf{N} \quad$ If no, type ctrl- $n$ pl Date issued for construction (MM / YYYY):

Project Number

Minimum channel bed elevation:

Low superstructure elevation: USLAB DSLAB USRAB DSRAB Benchmark location description:

NO BENCHMARK INFORMATION

Reference Point (MSL, Arbitrary, Other):

Datum (NAD27, NAD83, Other):

Foundation Type: 4

If 1: Footing Thickness

If 2: Pile Type: (1-Wood; 2-Steel or metal; 3-Concrete)

(1-Spreadfooting; 2-Pile; 3- Gravity; 4-Unknown)

If 3 : Footing bottom elevation:

Is boring information available? $\mathbf{N}$ If no, type ctrl-n bi Number of borings taken:

Foundation Material Type: 3 (1-regolith, 2-bedrock, 3-unknown)

Briefly describe material at foundation bottom elevation or around piles:

NO FOUNDATION MATERIAL INFORMATION

Comments:

Plans are in production for the proposed structure to replace the current bridge. The new bridge is to be a single span. The bottom of the right abutment is now proposed at 591.75 feet and the left at 594.25 feet. 


\section{Cross-sectional Data}

Is cross-sectional data available? Yes If no, type ctrl-n xs

Source (FEMA, VTAOT, Other)? FEMA

Comments: The elevation and station measurements are in feet. The data only provides one low cord elevation for the entire bridge opening. Low cord does vary according to the 9/96 survey.

\begin{tabular}{|l|l|l|l|l|l|l|l|l|l|l|l|}
\hline Station & $\mathbf{3 2 2}$ & $\mathbf{3 2 8}$ & $\mathbf{3 3 5}$ & $\mathbf{3 4 0}$ & $\mathbf{3 4 3}$ & $\mathbf{3 5 2}$ & $\mathbf{3 5 5}$ & $\mathbf{3 7 0}$ & $\mathbf{3 8 5}$ & $\mathbf{3 8 8}$ & $\mathbf{3 9 5}$ \\
\hline Feature & LAB & - & - & - & - & - & - & - & - & - & - \\
\hline $\begin{array}{l}\text { Low cord } \\
\text { elevation }\end{array}$ & $\mathbf{5 9 5 . 3}$ & $\mathbf{5 9 5 . 3}$ & $\mathbf{5 9 5 . 3}$ & $\mathbf{5 9 5 . 3}$ & $\mathbf{5 9 5 . 3}$ & $\mathbf{5 9 5 . 3}$ & $\mathbf{5 9 5 . 3}$ & $\mathbf{5 9 5 . 3}$ & $\mathbf{5 9 5 . 3}$ & $\mathbf{5 9 5 . 3}$ & $\mathbf{5 9 5 . 3}$ \\
\hline $\begin{array}{l}\text { Bed } \\
\text { elevation }\end{array}$ & $\mathbf{5 9 2 . 8}$ & $\mathbf{5 9 2}$ & $\mathbf{5 8 9}$ & $\mathbf{5 8 5}$ & $\mathbf{5 8 4 . 2}$ & $\mathbf{5 8 2 . 5}$ & $\mathbf{5 8 2}$ & $\mathbf{5 8 3 . 1}$ & $\mathbf{5 8 3 . 7}$ & $\mathbf{5 8 4}$ & $\mathbf{5 8 3 . 1}$ \\
\hline $\begin{array}{l}\text { Low cord to } \\
\text { bed length }\end{array}$ & $\mathbf{2 . 5}$ & $\mathbf{3 . 3}$ & $\mathbf{6 . 3}$ & $\mathbf{1 0 . 3}$ & $\mathbf{1 1 . 1}$ & $\mathbf{1 2 . 8}$ & $\mathbf{1 3 . 3}$ & $\mathbf{1 2 . 1}$ & $\mathbf{1 1 . 6}$ & $\mathbf{1 1 . 3}$ & $\mathbf{1 2 . 2}$ \\
\hline Station & $\mathbf{4 0 3}$ & $\mathbf{4 0 9}$ & $\mathbf{4 1 8}$ & - & - & - & - & - & - & - & - \\
\hline Feature & - & - & $\mathbf{R A B}$ & - & - & - & - & - & - & - & - \\
\hline $\begin{array}{l}\text { Low cord } \\
\text { elevation }\end{array}$ & $\mathbf{5 9 5 . 3}$ & $\mathbf{5 9 5 . 3}$ & $\mathbf{5 9 5 . 3}$ & - & - & - & - & - & - & - & - \\
\hline $\begin{array}{l}\text { Bed } \\
\text { elevation }\end{array}$ & $\mathbf{5 8 2 . 6}$ & $\mathbf{5 8 7 . 9}$ & $\mathbf{5 8 9 . 4}$ & - & - & - & - & - & - & - & - \\
\hline $\begin{array}{l}\text { Low cord to } \\
\text { bed length }\end{array}$ & $\mathbf{1 2 . 7}$ & $\mathbf{7 . 4}$ & $\mathbf{5 . 9}$ & - & - & - & - & - & - & - & - \\
\hline
\end{tabular}

Source (FEMA, VTAOT, Other)?

Comments: -

\begin{tabular}{|l|l|l|l|l|l|l|l|l|l|l|l|}
\hline Station & - & - & - & - & - & - & - & - & - & - & - \\
\hline Feature & - & - & - & - & - & - & - & - & - & - & - \\
\hline $\begin{array}{l}\text { Low cord } \\
\text { elevation }\end{array}$ & - & - & - & - & - & - & - & - & - & - & - \\
\hline $\begin{array}{l}\text { Bed } \\
\text { elevation }\end{array}$ & - & - & - & - & - & - & - & - & - & - & - \\
\hline $\begin{array}{l}\text { Low cord to } \\
\text { bed length }\end{array}$ & - & - & - & - & - & - & - & - & - & - & - \\
\hline Station & - & - & - & - & - & - & - & - & - & - & - \\
\hline Feature & - & - & - & - & - & - & - & - & - & - & - \\
\hline $\begin{array}{l}\text { Low cord } \\
\text { elevation }\end{array}$ & - & - & - & - & - & - & - & - & - & - & - \\
\hline $\begin{array}{l}\text { Bed } \\
\text { elevation }\end{array}$ & - & - & - & - & - & - & - & - & - & - & - \\
\hline $\begin{array}{l}\text { Low cord to } \\
\text { bed length }\end{array}$ & - & - & - & - & - & - & - & - & - & - & - \\
\hline
\end{tabular}




\section{APPENDIX E: \\ LEVEL I DATA FORM}


U. S. Geological Survey

Bridge Field Data Collection and Processing Form

Qa/Qc Check by: EW

Date: $9 / 23 / 96$

Computerized by: $\mathbf{E W}$ Date: $\mathbf{9 / 2 3 / 9 6}$

\section{Structure Number CHESVT01030012}

Reviewd by: $\quad$ RF Date: $\underline{\mathbf{4} / 01 / 97}$

\section{A. General Location Descriptive}

1. Data collected by (First Initial, Full last name) R. BURNS

2. Highway District Number $\mathbf{0 2}$

Mile marker $\mathbf{0 0 3 8 3 0}$

County WINDSOR 027

Town CHESTER 13600

Waterway (I - 6) WILLIAMS RIVER

Route Number VT 103

Road Name -

Hydrologic Unit Code: $\mathbf{0 1 0 8 0 1 0 7}$

3. Descriptive comments:

LOCATED 0.8 MILES NORTH OF JUNCTION WITH VT 11 WEST, AND AT INTERSECTION

BETWEEN VT 103 AND GREEN MOUNTAIN TURNPIKE.

\section{B. Bridge Deck Observations}
4. Surface cover... LBUS 5
RBUS 5
LBDS 2
RBDS 4
Overall 4

(2b us, ds,lb,rb: 1- Urban; 2- Suburban; 3- Row crops; 4- Pasture; 5- Shrub- and brushland; 6- Forest; 7- Wetland)
5. Ambient water surface... US 1
UB 1
DS 1
(1- pool; 2- riffle)

6. Bridge structure type 2 (1- single span; 2- multiple span; 3- single arch; 4- multiple arch; 5- cylindrical culvert; 6- box culvert; or 7- other)
7. Bridge length 99
(feet)
Span length $\underline{\mathbf{3 1}}$
(feet)
Bridge width 28 (feet)

\section{Road approach to bridge:}
8. LB 2 RB 1
( 0 even, 1- lower, 2- higher)
9. LB
RB 1
(1-Paved, 2- Not paved)

10. Embankment slope (run / rise in feet / foot)

US left

US right

\begin{tabular}{|c|c|c|c|}
\hline \multicolumn{2}{|c|}{ Protection } & \multirow{2}{*}{ 13.Erosion } & 14.Severity \\
\hline 11.Type & 12.Cond. & - & $\mathbf{1}$ \\
\hline $\mathbf{0}$ & - & $\mathbf{2}$ & $\mathbf{1}$ \\
\hline $\mathbf{0}$ & - & $\underline{\mathbf{2}}$ & - \\
$\mathbf{5}$ & $\mathbf{1}$ & $\mathbf{0}$ & - \\
\hline $\mathbf{0}$ & - & $\mathbf{0}$ & - \\
\hline
\end{tabular}

Bank protection types: 0- none; 1- < 12 inches,

2- $<36$ inches; $3-<48$ inches;

4- < 60 inches; 5- wall / artificial levee

Bank protection conditions: 1- good; 2- slumped;

3- eroded; 4- failed

Erosion: 0 - none; 1- channel erosion; 2 -

road wash; 3- both; 4- other

Erosion Severity: 0 - none; 1- slight; 2- moderate; 3- severe

\section{Channel approach to bridge (BF):}

15. Angle of approach: $\mathbf{5}$

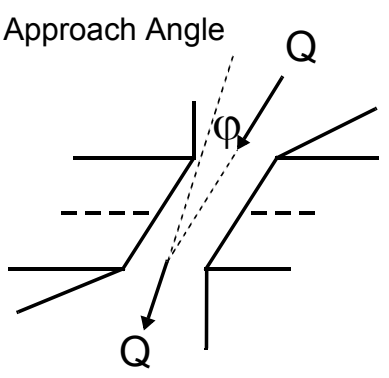

17. Channel impact zone 1:

Where? LB $(L B, R B)$

Range? 100 feet US

Channel impact zone 2:

Where? RB (LB, RB)

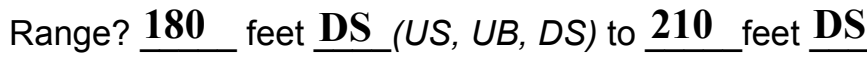

Impact Severity: 0- none to very slight; 1-Slight; 2- Moderate; 3- Severe
16. Bridge skew: 20

Bridge Skew Angle

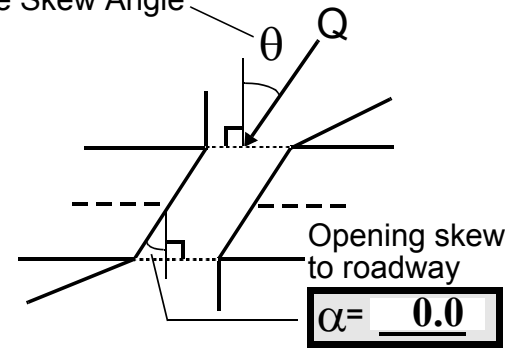

\section{Exist? $\mathbf{Y}(Y$ or $N)$}

Severity 1

(US, UB, DS) to $\underline{\mathbf{1 0}}$ feet $\underline{\mathbf{U S}}$

Exist? $\mathbf{Y}(Y$ or $N)$

Severity 1

o roadway

$\underline{0}$


18. Bridge Type: $\mathbf{1 b}$

1a- Vertical abutments with wingwalls

$1 \mathrm{~b}$ - Vertical abutments without wingwalls

2- Vertical abutments and wingwalls, sloping embankment

Wingwalls perpendicular to abut. face

3- Spill through abutments

4- Sloping embankment, vertical wingwalls and abutments

Wingwall angle less than $90^{\circ}$.

19. Bridge Deck Comments (surface cover variations, measured bridge and span lengths, bridge type variations, approach overflow width, etc.)

\#4: Surface cover along the banks upstream is forest with lawns or fields beyond two bridge lengths.

\#7: Measured bridge length $=99$ feet; span length between piers $=33$ feet and bridge width $=28$ feet.

\#11: Road embankment protection on the DSRB is an artificial levee built up from when the drop structure was a dam for the mill.

\#13: Road wash erosion may be foot paths under the bridge.

\section{Upstream Channel Assessment}

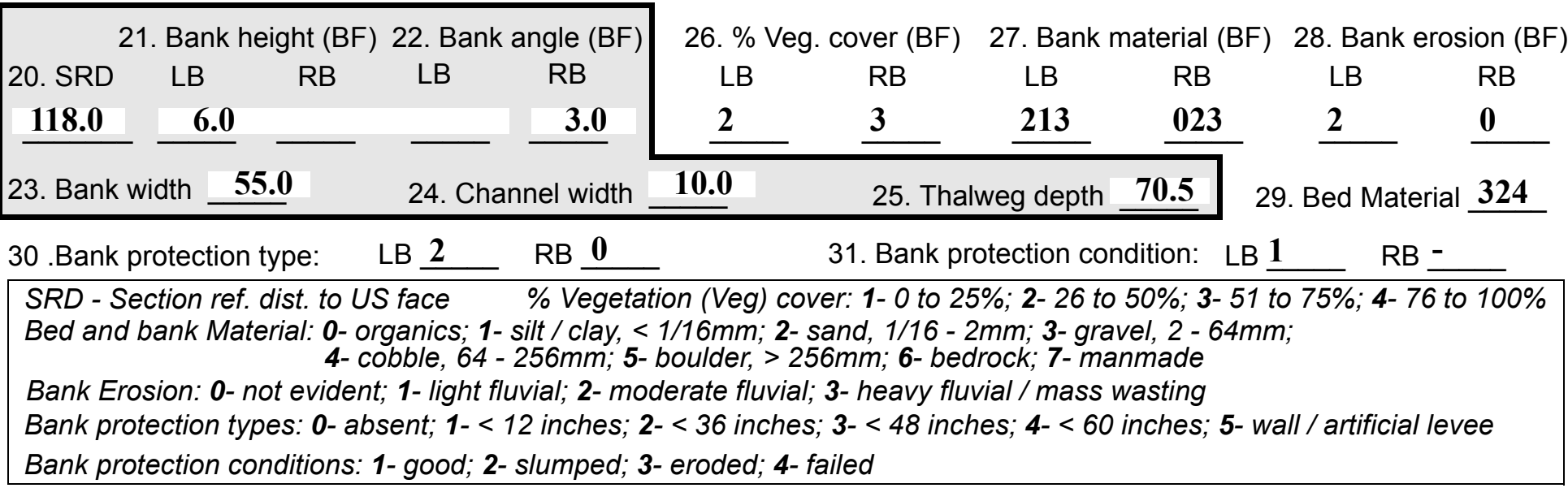

32. Comments (bank material variation, minor inflows, protection extent, etc.):

\#29: From 65 feet upstream to the upstream bridge face, the bed material in the right half of the channel is primarily sand.

\#30: The left bank protection extends from the upstream bridge face to 46 feet upstream. 
36. Point bar extent: $\underline{\mathbf{3 0 0}}$ feet $\underline{\mathrm{US}}$ (US, UB) to $\underline{\mathbf{3 6}}$ feet $\underline{\mathrm{US}}$ (US, UB, DS) positioned $\underline{\mathbf{5 0}} \%$ LB to $\underline{\mathbf{1 0 0}} \%$ RB

37. Material: $\mathbf{2 3 4}$

38. Point or side bar comments (Circle Point or Side; Note additional bars, material variation, status, etc.):

Point bar is completely vegetated with shrubs and brush along the right bank. From 150 feet upstream to 300 feet upstream, the point bar is composed primarily of gravel.

39. Is a cut-bank present? $\underline{\mathbf{Y}}$ ( $Y$ or if $N$ type ctrl-n cb)

40. Where? $\mathbf{L B}$ (LB or RB)

41. Mid-bank distance: 127

42. Cut bank extent: 199

(US, $U B)$ to 46 feet US (US, UB, DS)

43. Bank damage: 1

(1- eroded and/or creep; 2- slip failure; 3- block failure)

44. Cut bank comments (eg. additional cut banks, protection condition, etc.):

Above the cut-bank, there is an old stone wall from 226 feet upstream to 81 feet upstream.

45. Is channel scour present? $\mathbf{Y}$ ( $Y$ or if $N$ type ctrl-n cs) 46. Mid-scour distance: $\underline{\mathbf{O} \text { US }}$

47. Scour dimensions: Length $\underline{\mathbf{1 2 5}}$ Width $\underline{\mathbf{3 5}}$ Depth: $\underline{\mathbf{3 . 2 5}}$ Position $\underline{\mathbf{1 0}} \% \mathrm{LB}$ to $\underline{\mathbf{9 0}} \% \mathrm{RB}$

48. Scour comments (eg. additional scour areas, local scouring process, etc.):

The scour hole extends from 78 feet upstream along the left bank, then between the piers, and continues to 25

feet downstream. The thalweg depth is assumed to be 2.0 feet.

49. Are there major confluences? $\mathbf{N}$

51. Confluence 1: Distance -

Confluence 2: Distance -

NO MAJOR CONFLUENCES
(Y or if $N$ type ctrl-n mc)

52. Enters on -

Enters on ( $L B$ or $R B)$ ( $L B$ or $R B)$
50. How many? -

53. Type(1-perennial; 2- ephemeral)

Type (1-perennial; 2- ephemeral)

\section{Under Bridge Channel Assessment}

55. Channel restraint (BF)? LB 2

56. Height (BF)
LB RB
$\mathbf{3 7 . 0}-$
58. Bank width (BF) =
(1- natural bank; 2- abutment; 3- artificial levee)

Bed and bank Material: 0- organics; 1- silt / clay, < 1/16mm; 2- sand, 1/16 - 2mm; 3- gravel, 2 - 64mm; 4- cobble, 64 - 256mm; 5- boulder, > 256mm; 6- bedrock; 7- manmade

Bank Erosion: 0- not evident; 1- light fluvial; 2- moderate fluvial; 3- heavy fluvial / mass wasting

64. Comments (bank material variation, minor inflows, protection extent, etc.):

243

The stream channel makes a sharp bend just upstream of the bridge. Most of the flow is between the piers. 
65. Debris and Ice Is there debris accumulation?

(Yor $N)$ 66. Where? $\underline{Y}$

(1- Upstream; 2- At bridge; 3- Both)

67. Debris Potential $\underline{2}$ ( 1-Low; 2- Moderate; 3- High)

68. Capture Efficiency 2 (1-Low; 2- Moderate; 3- High)

69. Is there evidence of ice build-up? $\underline{2}$ (Yor $N)$

Ice Blockage Potential $\mathbf{N}$

(1-Low; 2-Moderate; 3- High)

70. Debris and Ice Comments:

2

There is debris caught along the front and right side of the right pier.

\begin{tabular}{|l|c|c|c|c|c|c|c|c|}
\hline Abutments & $\begin{array}{c}71 . \text { Attack } \\
\angle \text { (BF) }\end{array}$ & $\begin{array}{c}72 \text {. Slope } \angle \\
\text { (Qmax) }\end{array}$ & $\begin{array}{c}\text { 73. Toe } \\
\text { loc. (BF) }\end{array}$ & $\begin{array}{c}\text { 74. Scour } \\
\text { Condition }\end{array}$ & $\begin{array}{c}75 . \text { Scour } \\
\text { depth }\end{array}$ & $\begin{array}{c}\text { 76. Exposure } \\
\text { depth }\end{array}$ & 77. Material & 78. Length \\
\hline LABUT & & - & $\mathbf{9 0}$ & $\mathbf{0}$ & $\mathbf{0}$ & - & - & $\mathbf{9 0 . 0}$ \\
\hline RABUT & $\mathbf{1}$ & $\mathbf{4 5}$ & $\mathbf{9 0}$ & & & $\mathbf{0}$ & $\mathbf{0}$ & $\mathbf{9 5 . 5}$ \\
\hline
\end{tabular}

Pushed: $L B$ or RB

Toe Location (Loc.): 0- even, 1- set back, 2- protrudes

Scour cond.: 0- not evident; 1- evident (comment); 2- footing exposed; 3-undermined footing; 4- piling exposed; 5- settled; 6- failed

Materials: 1- Concrete; 2- Stone masonry or drywall; 3- steel or metal; 4- wood

79. Abutment comments (eg. undermined penetration, unusual scour processes, debris, etc.):

-

1

Stone fill protection in front of the abutments is similar to a spill-through type. The stone fill along the abutment is at a 35 degree angle. The protection also protrudes into the channel while the concrete part of the abutment is even with the top of bank.

80. Wingwalls:

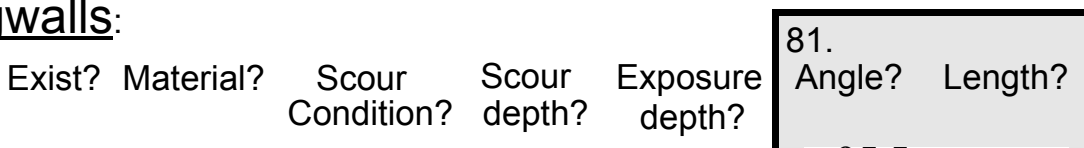

USLWW:

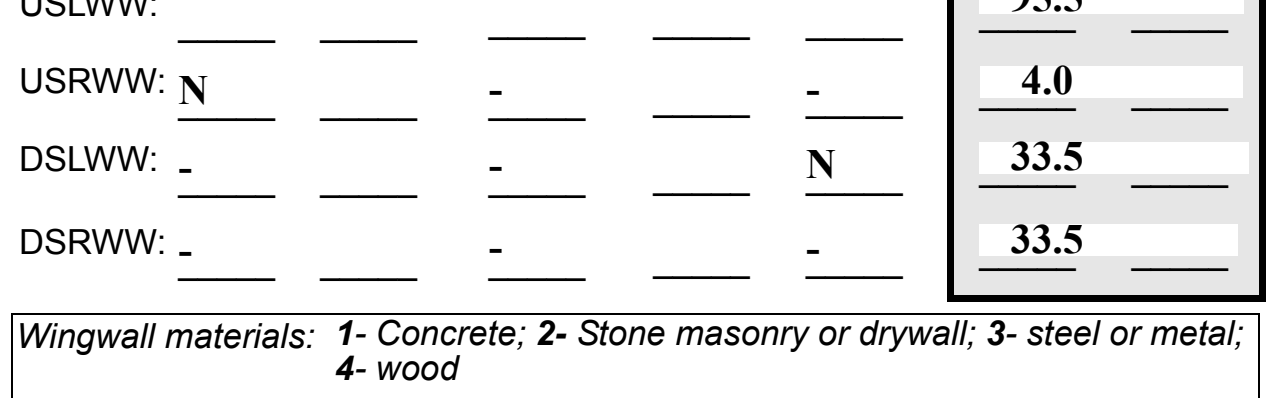

95.5

4- wood

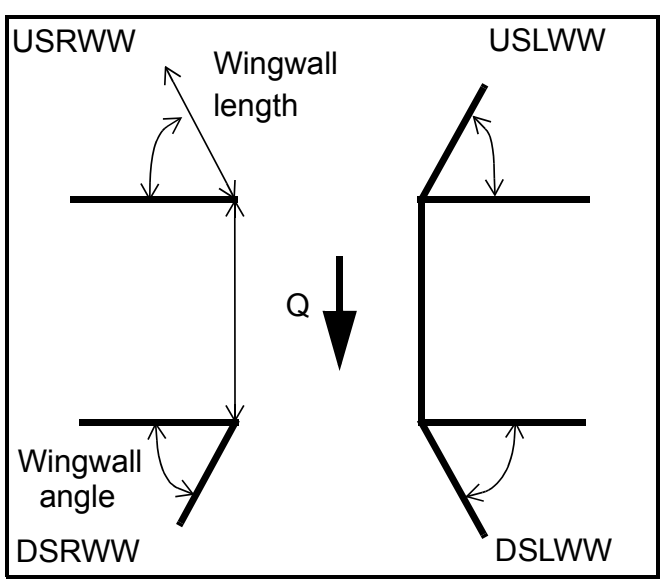

82. Bank / Bridge Protection:

\begin{tabular}{|l|l|l|l|l|l|l|l|c|}
\hline Location & USLWW & USRWW & LABUT & RABUT & LB & RB & DSLWW & DSRWW \\
\hline Type & - & - & N & - & - & - & $\mathbf{1}$ & $\mathbf{1}$ \\
\hline Condition & N & - & - & - & - & - & $\mathbf{1}$ & $\mathbf{1}$ \\
\hline Extent & - & - & - & - & - & $\mathbf{2}$ & $\mathbf{2}$ & - \\
\hline
\end{tabular}

Bank / Bridge protection types: 0- absent; 1- < 12 inches; 2- < 36 inches; 3- < 48 inches; 4- < 60 inches; 
83. Wingwall and protection comments (eg. undermined penetration, unusual scour processes, etc.):

$-$

$-$

$-$

$-$

$-$

$-$

$-$

$-$

$-$

$-$

\section{Piers:}

84. Are there piers? _ _ (Y or if $N$ type ctrl-n pr)

\begin{tabular}{|l|l|l|l|l|l|l|l|}
\hline \multirow{2}{*}{$\begin{array}{l}85 . \\
\text { Pier no. }\end{array}$} & \multicolumn{3}{|c|}{ width $(\mathrm{w})$ feet } & \multicolumn{3}{|c|}{ elevation (e) feet } \\
\cline { 2 - 8 } & w1 & w2 & w3 & e@w1 & e@w2 & e@w3 \\
\hline Pier 1 & - & - & - & - & - & - \\
\hline Pier 2 & - & $\mathbf{2 . 0}$ & $\mathbf{3 . 2 5}$ & - & $\mathbf{4 9 6 . 1 3}$ & $\mathbf{4 8 3 . 2 0}$ \\
\hline Pier 3 & - & $\mathbf{2 . 0}$ & $\mathbf{3 . 2 5}$ & - & $\mathbf{4 9 5 . 8 1}$ & $\mathbf{4 8 0 . 3 0}$ \\
\hline Pier 4 & - & - & - & - & - & - & w1 \\
\hline
\end{tabular}

\begin{tabular}{|l|l|l|l|l|}
\hline Level 1 Pier Descr. & \multicolumn{1}{|c|}{1} & \multicolumn{1}{|c|}{2} & \multicolumn{1}{|c|}{4} & 4 \\
\hline 86. Location (BF) & & L & MCR & \\
\hline 87. Type & & $\mathbf{1}$ & $\mathbf{1}$ & \\
\hline 88. Material & & $\mathbf{2}$ & $\mathbf{2}$ & \\
\hline 89. Shape & & $\mathbf{1}$ & $\mathbf{1}$ & \\
\hline 90. Inclined? & & $\mathbf{N}$ & $\mathbf{N}$ & \\
\hline 91. Attack $\angle$ (BF) & & - & $\mathbf{4 5}$ & \\
\hline 92. Pushed & & $\mathbf{R B}$ & $\mathbf{L B}$ & \\
\hline 93. Length (feet) & - & - & - & - \\
\hline 94. \# of piles & & $\mathbf{U N K}$ & $\mathbf{U N K}$ & \\
\hline 95. Cross-members & & $\mathbf{0}$ & $\mathbf{0}$ & \\
\hline 96. Scour Condition & & $\mathbf{1}$ & $\mathbf{1}$ & \\
\hline 97. Scour depth & $\mathbf{Y}$ & $\mathbf{3 . 2 5}$ & $\mathbf{2 . 0}$ & \\
\hline 98. Exposure depth & MC & $\mathbf{0}$ & $\mathbf{0}$ & \\
\hline
\end{tabular}

LFP, LTB, LB, MCL, MCM, MCR, RB, RTB, RFP

1- Solid pier, 2-column, 3- bent

1-Wood; 2-concrete; 3- metal; 4- stone

1- Round; 2- Square; 3- Pointed

Y-yes; $N$ - no

$L B$ or $R B$

0- none; 1- laterals; 2- diagonals; 3- both

0- not evident; 1- evident (comment);

2- footing exposed; 3- piling exposed;

4- undermined footing; 5- settled; 6- failed 
99. Pier comments (eg. undermined penetration, protection and protection extent, unusual scour processes, etc.):

100.

\section{E. Downstream Channel Assessment}

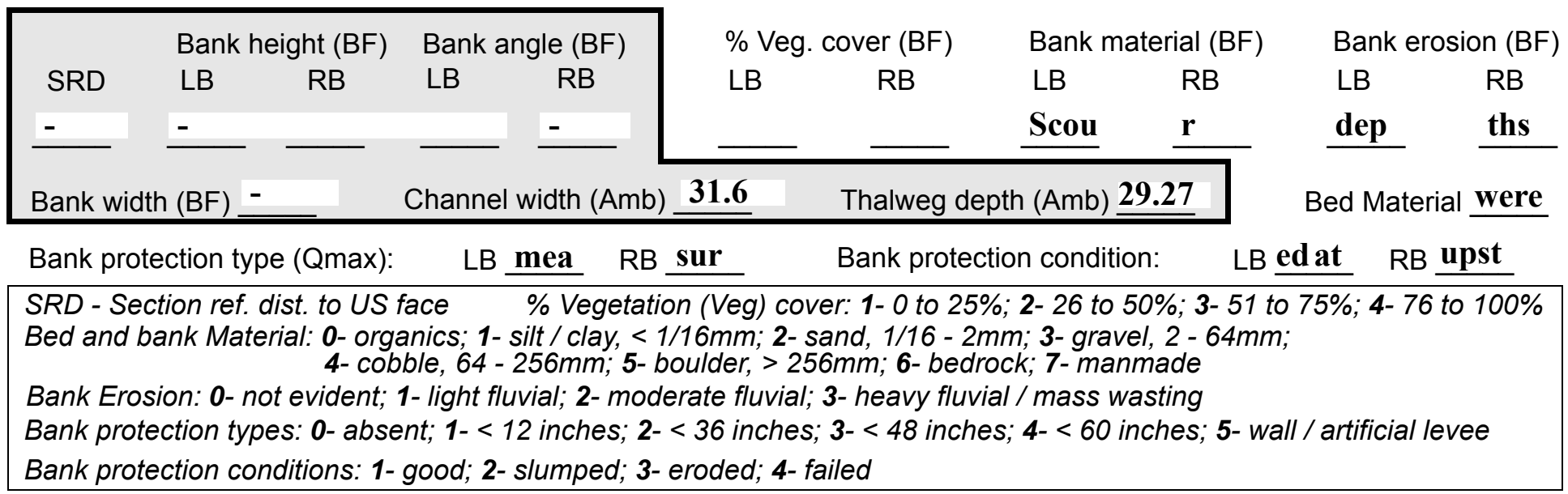

Comments (eg. bank material variation, minor inflows, protection extent, etc.):

ream end of piers.

101. Is a drop structure present? 1 ( $Y$ or $N$, if $N$ type ctrl-n ds) 102. Distance: ___ feet

103. Drop:-___ feet 104. Structure material: $\underline{\mathbf{3 4 2}}$ (1- steel sheet pile; 2- wood pile; 3- concrete; 4- other) 105. Drop structure comments (eg. downstream scour depth):

5

$2 / 5$

1

1

On the left bank there is a stone wall in-line with the abutment from the bridge face to 88 feet downstream. From $88 \mathrm{ft}$ downstream to 200 feet downstream, the rock wall is along the left edge of water . 
106. Point/Side bar present? (Y or N. if $N$ type ctrl-n pb)Mid-bar distance: On Mid-bar width: the

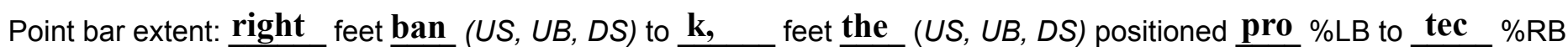
Material: tio

Point or side bar comments (Circle Point or Side; note additional bars, material variation, status, etc.):

$\mathrm{n}$ extends from the bridge face to 70 feet downstream. There is a section of no protection from $\mathbf{7 0} \mathbf{f t}$ downstream to $124 \mathrm{ft}$ downstream which is then followed by a rock wall extending from 124 feet downstream to 224 feet downstream.

Is a cut-bank present? $\mathbf{C h}$ (Y or if $N$ type ctrl- $n c b)$ Where? este (LB or RB) Mid-bank distance: $\underline{\mathbf{r}}$ Cut bank extent: brid feet ge (US, UB, DS) to $\underline{\mathbf{6 3}}$ is feet $\underline{400}$ (US, UB, DS)

Bank damage: feet (1- eroded and/or creep; 2- slip failure; 3- block failure)

Cut bank comments (eg. additional cut banks, protection condition, etc.):

downstream from this bridge.

Is channel scour present? ( $Y$ or if $N$ type ctrl-n cs)

Mid-scour distance:

Scour dimensions: Length Width Depth: $\mathbf{Y}$

Positioned 2

$\%$ LB to $\underline{\text { The }} \%$ RB

Scour comments (eg. additional scour areas, local scouring process, etc.):

drop structure, which is the remnant of an old dam, is located approximately 62 feet downstream.

At approximately 70 feet downstream, there is another drop structure which was the base of the downstream face of the dam. The structure drops 2 feet and the water depth is 0.3 feet over the top of the structure.

Are there major confluences?

Confluence 1: Distance $\mathbf{Y}$

Confluence 2: Distance 146

( $Y$ or if $N$ type ctrl-n $m c$ )

How many?

Enters on $\frac{197}{\mathbf{D S}}$ (LB or RB)

Type 22

(1- perennial; 2- ephemeral)

Confluence comments (eg. confluence name):

DS

10

\section{F. Geomorphic Channel Assessment}

107. Stage of reach evolution $\mathbf{8 0}$

1- Constructed

2- Stable

3- Aggraded

4- Degraded

5- Laterally unstable

6- Vertically and laterally unstable 
108. Evolution comments (Channel evolution not considering bridge effects; See HEC-20, Figure 1 for geomorphic descriptors):

324

This is a mid-channel bar which is vegetated with grass and some shrubs. The left side of the mid-channel bar is composed primarily of sand, while the right side of the mid-channel bar is composed primarily of gravel.

Y

RB

268

224

DS

312

DS 


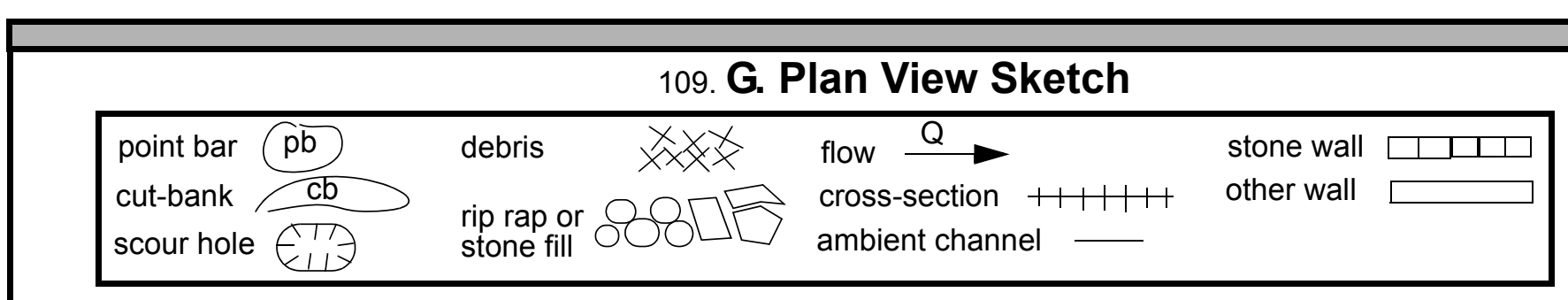

cut-bank $\mathrm{cb}$

scour hole rip rap or
stone fill stone wa 
APPENDIX F:

SCOUR COMPUTATIONS 
SCOUR COMPUTATIONS

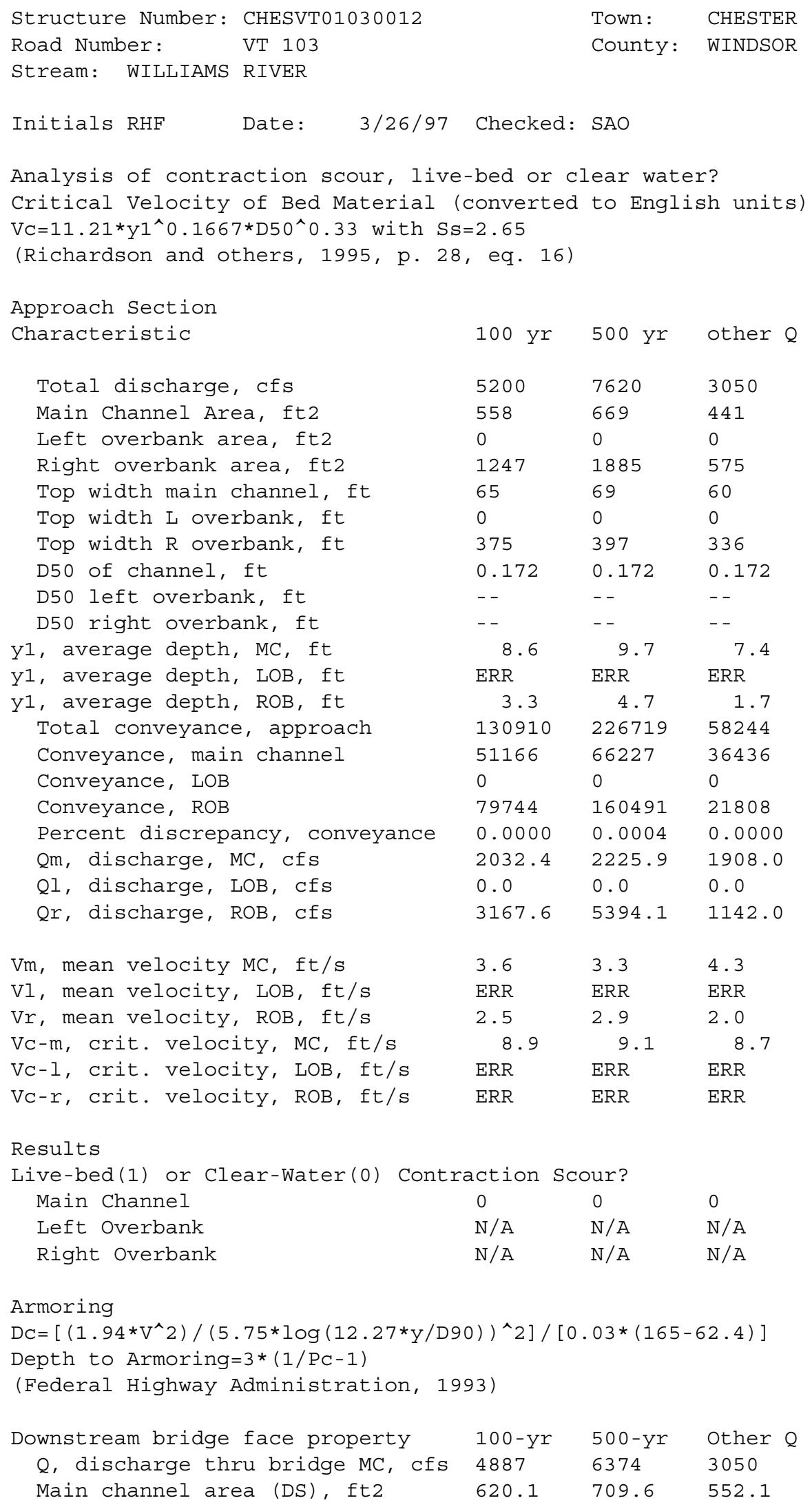




\begin{tabular}{|c|c|c|c|}
\hline Main channel width (normal), ft & 82.2 & 88.1 & 78.1 \\
\hline Cum. width of piers, ft & 0.0 & 0.0 & 0.0 \\
\hline Adj. main channel width, ft & 82.2 & 88.1 & 78.1 \\
\hline $90, \mathrm{ft}$ & 0.3157 & 0.3157 & 0.3157 \\
\hline ft & 0.3772 & 0.3772 & 0.3772 \\
\hline critical & 0.1945 & 0.2470 & 0.0978 \\
\hline coarser than DC & 0.369 & 0.207 & 0.888 \\
\hline epth to armoring & 1.00 & 2.84 & 0.04 \\
\hline
\end{tabular}

Clear Water Contraction Scour in MAIN CHANNEL

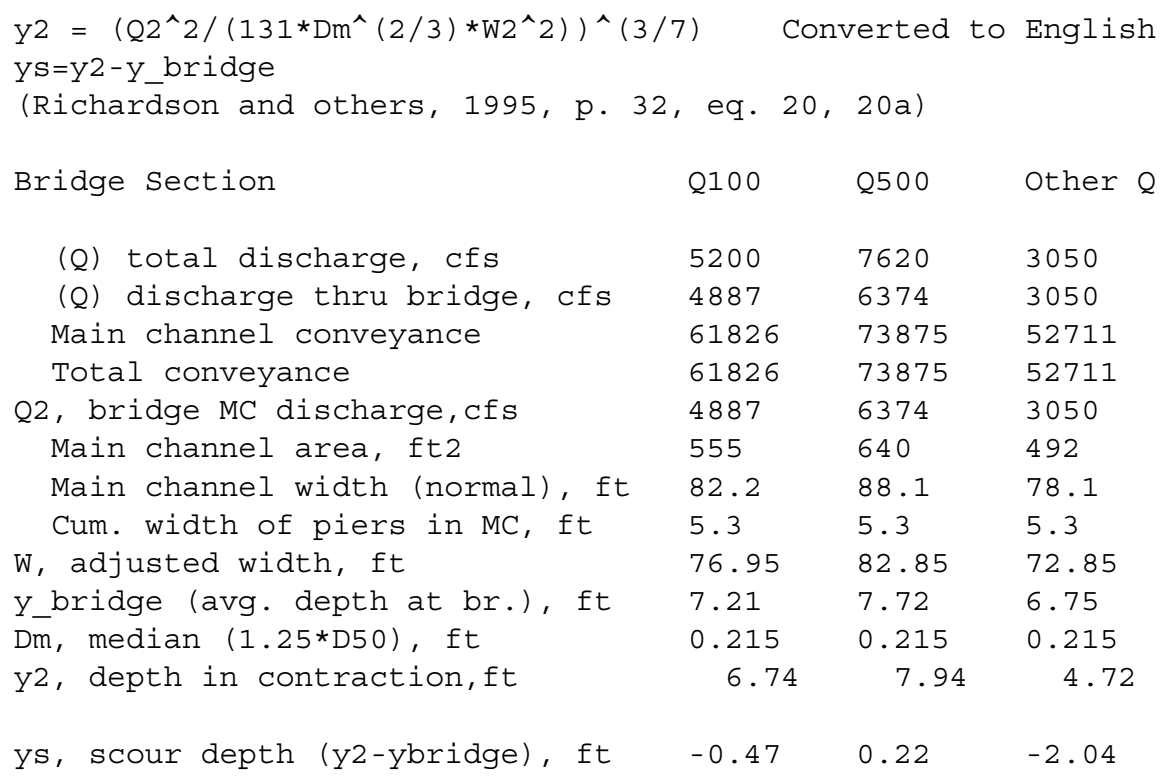

Abutment Scour

Froehlich's Abutment Scour

$\mathrm{Ys} / \mathrm{Y} 1=2.27 * \mathrm{~K} 1 * \mathrm{~K} 2 *\left(\mathrm{a}^{\prime} / \mathrm{Y} 1\right)^{\wedge} 0.43 * \mathrm{Fr} 1^{\wedge} 0.61+1$

(Richardson and others, 1995, p. 48, eq. 28)

Characteristic

Left Abutment

Right Abutment

100 yr Q 500 yr Q Other Q 100 yr Q 500 yr Q Other Q

\begin{tabular}{|c|c|c|c|c|c|c|}
\hline (Qt), total discharge, cfs & 5200 & 7620 & 3050 & 5200 & 7620 & 3050 \\
\hline a', abut.length blocking flow, ft & 12 & 15.6 & 7.65 & 305.7 & 271.05 & 340 \\
\hline Ae, area of blocked flow ft 2 & 70.56 & 104.72 & 40.75 & 1051.91 & 1389.59 & 524.2 \\
\hline 2e, discharge blocked abut., cfs & 178.29 & 247.65 & 119.04 & 2672.55 & 3898.5 & 1018.86 \\
\hline (If using Qtotal_ & in $\mathrm{Ve}$, & ive Qe & lank and & enter Ve & and Fr mar & גally) \\
\hline Ve, $(\mathrm{Qe} / \mathrm{Ae}), \mathrm{ft} / \mathrm{s}$ & 2.53 & 2.36 & 2.92 & 2.54 & 2.81 & 1.94 \\
\hline ya, depth of $\mathrm{f} / \mathrm{p}$ flow, ft & 5.88 & 6.71 & 5.33 & 3.44 & 5.13 & 1.54 \\
\hline --Coeff., K1, for abut. type $(1.0$, & verti & $0.82, \quad v \in$ & ti. w/ & gwall; 0 & .55, spil & lthru) \\
\hline K1 & 0.55 & 0.55 & 0.55 & 0.55 & 0.55 & 0.55 \\
\hline lkment & if $a b$ & points & $S ;>90$ & abut. po: & ints US) & \\
\hline thet & 90 & 90 & 90 & 90 & 90 & 90 \\
\hline K2 & 1.00 & 1.00 & 1.00 & 1.00 & 1.00 & 1.00 \\
\hline r, froude number $\mathrm{f} / \mathrm{p}$ flow & 0.184 & 0.161 & 0.223 & 0.241 & 0.218 & 0.276 \\
\hline
\end{tabular}




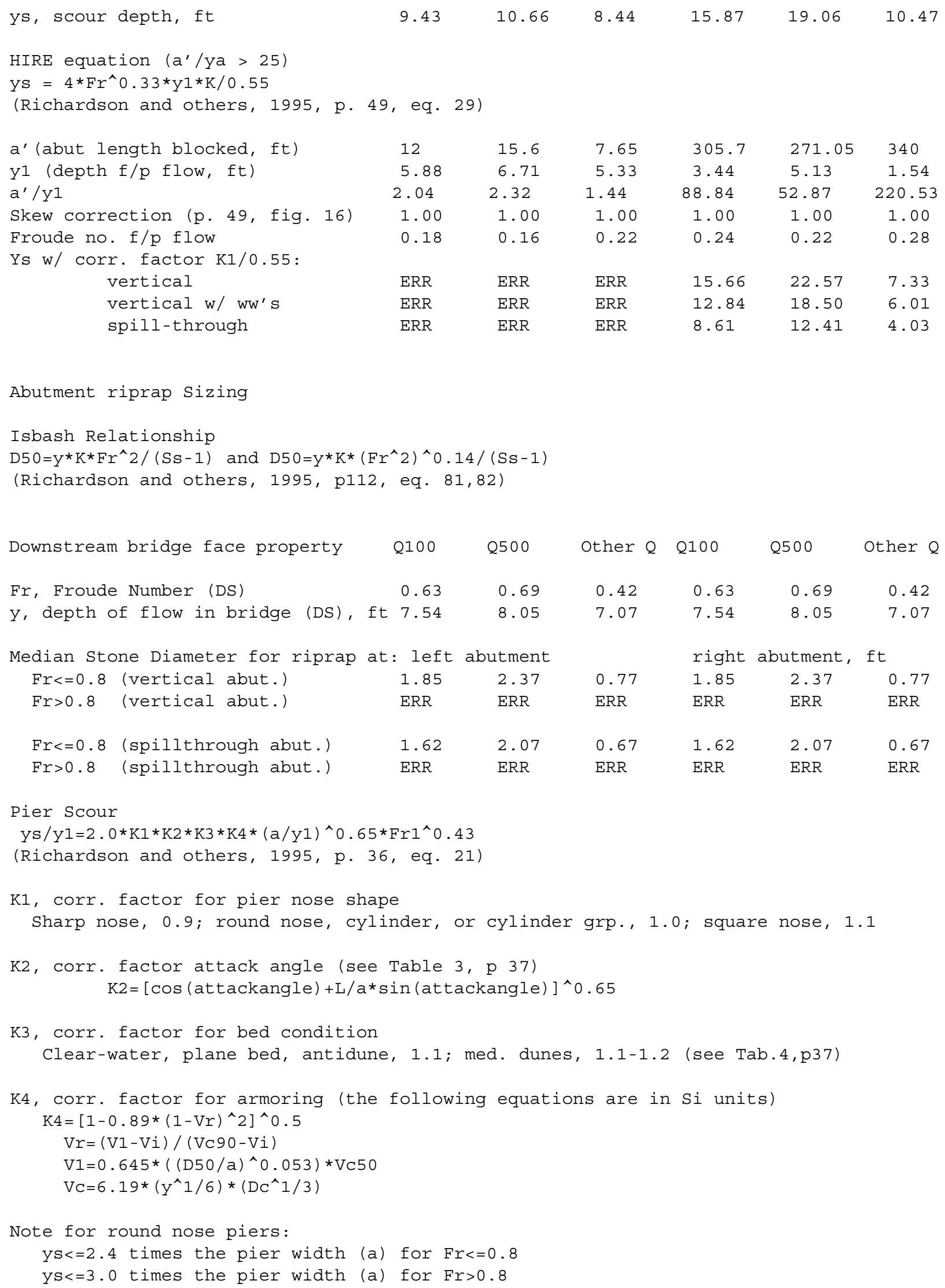


Pier 1

Pier stationing, ft

$\begin{array}{lll}\text { Q100 } & \text { Q500 } & \text { Qother } \\ 31.1 & 31.1 & 31.1 \\ 25.4 & 28.9 & 22.3 \\ 2.2 & 2.2 & 2.1 \\ 11.55 & 13.14 & 10.62 \\ 3.519 & 4.004 & 3.237 \\ 9.62 & 11.04 & 6.84 \\ 3.25 & 3.25 & 3.25 \\ 31.6 & 31.6 & 31.6 \\ 0.499 & 0.537 & 0.370 \\ 0 & 0 & 0 \\ 1 & 1 & 1 \\ 1.00 & 1.00 & 1.00 \\ 1.1 & 1.1 & 1.1 \\ 0.172 & 0.172 & 0.172 \\ 0.052423 & 0.052423 & 0.052423 \\ 0.3157 & 0.3157 & 0.3157 \\ 0.096221 & 0.096221 & 0.096221 \\ 2.857 & 2.919 & 2.818 \\ 3.498 & 3.574 & 3.450 \\ 1.577 & 1.611 & 1.555 \\ 0.705 & 0.893 & 0.279 \\ 0.00 & 0.00 & 0.00 \\ \text { ERR } & \text { ERR } & \text { ERR } \\ 8.26 & 8.92 & 7.06 \\ & & \end{array}$

skewed width of flow tube, ft

y1, pier approach depth, ft

$\mathrm{y} 1$ in meters

V1, pier approach velocity, ft/s

a, pier width, ft

L, pier length, ft

Frl, Froude number at pier

Pier attack angle, degrees

K1, shape factor

K2, attack factor

K3, bed condition factor

D50, ft

D50, m

D90, ft

D90, m

Vc50, critical velocity (D50), m/s

Vc90, critical velocity (D90), m/s

Vi, incipient velocity, m/s

Vr, velocity ratio

K4, armor factor

ys, scour depth (K4 applicable) ft

ys, scour depth (K4 not applied) ft

Pier 2

Q100 Q500 Qother

Pier stationing, ft

Area of WSPRO flow tube, ft2

Skewed width of flow tube, ft

y1, pier approach depth, ft

y1 in meters

V1, pier approach velocity, ft/s

a, pier width, ft

L, pier length, ft

$\begin{array}{lll}64.1 & 64.1 & 64.1\end{array}$

$25.4 \quad 28.9 \quad 22.3$

$\begin{array}{lll}2.2 & 2.2 & 2.1\end{array}$

$\begin{array}{lll}11.55 & 13.14 & 10.62\end{array}$

$\begin{array}{lll}3.519 & 4.004 & 3.237\end{array}$

$\begin{array}{lll}9.62 & 11.04 & 6.84\end{array}$

$\begin{array}{lll}3.25 & 3.25 & 3.25\end{array}$

$\begin{array}{lll}32.5 & 32.5 & 32.5\end{array}$

Frl, Froude number at pier

Pier attack angle, degrees

K1, shape factor

$\mathrm{K} 2$, attack factor

K3, bed condition factor

D50, ft

D50, m

D90, ft

$\begin{array}{lll}0.499 & 0.537 & 0.370\end{array}$

$\begin{array}{lll}10 & 10 & 10\end{array}$

$\begin{array}{lll}1 & 1 & 1\end{array}$

$\begin{array}{lll}1.92 & 1.92 & 1.92\end{array}$

$\begin{array}{lll}1.1 & 1.1 & 1.1\end{array}$

$\begin{array}{lll}0.172 & 0.172 & 0.172\end{array}$

D90, m

$\begin{array}{llll}0.052423 & 0.052423 & 0.052423\end{array}$

$\begin{array}{llll}0.3157 & 0.3157 & 0.3157\end{array}$

Vc50, critical velocity(D50), m/s

$\begin{array}{llll}0.096221 & 0.096221 & 0.096221\end{array}$

Vc90, critical velocity(D90), m/s

$\begin{array}{lll}2.857 & 2.919 & 2.818\end{array}$

$\mathrm{Vi}$, incipient velocity, $\mathrm{m} / \mathrm{s}$

3.498

2.919
3.574

3.450

$\begin{array}{lll}1.577 & 1.611 & 1.555\end{array}$

Vr, velocity ratio

$0.705 \quad 0.893$

0.279

K4, armor factor

0.00

Ys, scour depth, (K4 applicable) ft ERR

0.00

0.00

ys, scour depth, (K4 not applied) ft $15.84 \quad 17.10 \quad 13.53$

Pier rip-rap sizing

$\mathrm{D} 50=0.692(\mathrm{~K} * \mathrm{~V})^{\wedge} 2 /(\mathrm{Ss}-1) * 2 * \mathrm{~g}$

(Richardson and others, 1995, p.115, eq. 83)

Pier-shape coefficient (K), round nose, 1.5; square nose, 1.7

Characteristic avg. channel velocity, $\mathrm{V},(\mathrm{Q} / \mathrm{A})$ : 
(Mult. by 0.9 for bankward piers in a straight, uniform reach, up to 1.7 for a pier in main current of flow around a bend)

Pier 1

$\mathrm{K}$, pier shape coeff.

$\mathrm{V}$, velocity on pier, ft/s

D50, median stone diameter, ft

Pier 2

$\mathrm{K}$, pier shape coeff.

$\mathrm{V}$, velocity on pier, ft/s

D50, median stone diameter, ft
Q100 Q500 Qother

$\begin{array}{lll}1.5 & 1.5 & 1.5\end{array}$

$\begin{array}{lll}7.62 & 8.67 \quad 5.41\end{array}$

$\begin{array}{lll}0.85 & 1.10 & 0.43\end{array}$

$\begin{array}{lll}1.5 & 1.5 & 1.5 \\ 7.62 & 8.67 & 5.41 \\ 0.85 & 1.10 & 0.43\end{array}$

